\title{
Overview: Precipitation characteristics and sensitivities to environmental conditions during GoAmazon2014/5 and ACRIDICON-CHUVA
}

\author{
Luiz A. T. Machado ${ }^{1}$, Alan J. P. Calheiros ${ }^{1}$, Thiago Biscaro ${ }^{1}$, Scott Giangrande $^{2}$, Maria A. F. Silva Dias ${ }^{3}$, \\ Micael A. Cecchini ${ }^{3}$, Rachel Albrecht ${ }^{3}$, Meinrat O. Andreae ${ }^{4,14}$, Wagner F. Araujo ${ }^{1}$, Paulo Artaxo ${ }^{5}$, \\ Stephan Borrmann ${ }^{4}$, Ramon Braga ${ }^{1}$, Casey Burleyson ${ }^{6}$, Cristiano W. Eichholz ${ }^{1}$, Jiwen Fan ${ }^{6}$, Zhe Feng $^{6}$, \\ Gilberto F. Fisch ${ }^{8}$, Michael P. Jensen ${ }^{2}$, Scot T. Martin ${ }^{7}$, Ulrich Pöschl ${ }^{4}$, Christopher Pöhlker ${ }^{4}$, Mira L. Pöhlker ${ }^{4}$, \\ Jean-François Ribaud ${ }^{1}$, Daniel Rosenfeld ${ }^{9}$, Jaci M. B. Saraiva ${ }^{10}$, Courtney Schumacher ${ }^{11}$, Ryan Thalman $^{12}$, \\ David Walter $^{4}$, and Manfred Wendisch ${ }^{13}$ \\ ${ }^{1}$ National Institute for Space Research (INPE), Sao José dos Campos, Brazil \\ ${ }^{2}$ Brookhaven National Laboratory, Upton, New York, USA \\ ${ }^{3}$ Institute of Astronomy, Geophysics, and Atmospheric Sciences, University of São Paulo, São Paulo, Brazil \\ ${ }^{4}$ Max Planck Institute for Chemistry, Mainz, Germany \\ ${ }^{5}$ Institute of Physics, University of São Paulo, São Paulo, Brazil \\ ${ }^{6}$ Pacific Northwest National Laboratory, Richland, WA, USA \\ ${ }^{7}$ Harvard University, Cambridge, Massachusetts, USA \\ ${ }^{8}$ Department of Aerospace Science and Technology, São José dos Campos, Brazil \\ ${ }^{9}$ Hebrew University of Jerusalem, Jerusalem, Israel \\ ${ }^{10}$ Amazon Protection System (SIPAM), Manaus, Brazil \\ ${ }^{11}$ Texas A \& M University, College Station, Texas, USA \\ ${ }^{12}$ Snow College, Richfield, UT, USA \\ ${ }^{13}$ Leipzig Institute for Meteorology, Leipzig University, Leipzig, Germany \\ ${ }^{14}$ Scripps Institution of Oceanography, University of California, San Diego, CA 92037, USA
}

Correspondence: Luiz A. T. Machado (luiz.machado@inpe.br)

Received: 24 October 2017 - Discussion started: 1 November 2017

Revised: 10 April 2018 - Accepted: 17 April 2018 - Published: 7 May 2018

\begin{abstract}
This study provides an overview of precipitation processes and their sensitivities to environmental conditions in the Central Amazon Basin near Manaus during the GoAmazon2014/5 and ACRIDICON-CHUVA experiments. This study takes advantage of the numerous measurement platforms and instrument systems operating during both campaigns to sample cloud structure and environmental conditions during 2014 and 2015; the rainfall variability among seasons, aerosol loading, land surface type, and topography has been carefully characterized using these data. Differences between the wet and dry seasons were examined from a variety of perspectives. The rainfall rates distribution, total amount of rainfall, and raindrop size distribution (the massweighted mean diameter) were quantified over both seasons.
\end{abstract}

The dry season generally exhibited higher rainfall rates than the wet season and included more intense rainfall periods. However, the cumulative rainfall during the wet season was 4 times greater than that during the total dry season rainfall, as shown in the total rainfall accumulation data. The typical size and life cycle of Amazon cloud clusters (observed by satellite) and rain cells (observed by radar) were examined, as were differences in these systems between the seasons. Moreover, monthly mean thermodynamic and dynamic variables were analysed using radiosondes to elucidate the differences in rainfall characteristics during the wet and dry seasons. The sensitivity of rainfall to atmospheric aerosol loading was discussed with regard to mass-weighted mean diameter and rain rate. This topic was evaluated only dur- 
ing the wet season due to the insignificant statistics of rainfall events for different aerosol loading ranges and the low frequency of precipitation events during the dry season. The impacts of aerosols on cloud droplet diameter varied based on droplet size. For the wet season, we observed no dependence between land surface type and rain rate. However, during the dry season, urban areas exhibited the largest rainfall rate tail distribution, and deforested regions exhibited the lowest mean rainfall rate. Airplane measurements were taken to characterize and contrast cloud microphysical properties and processes over forested and deforested regions. Vertical motion was not correlated with cloud droplet sizes, but cloud droplet concentration correlated linearly with vertical motion. Clouds over forested areas contained larger droplets than clouds over pastures at all altitudes. Finally, the connections between topography and rain rate were evaluated, with higher rainfall rates identified at higher elevations during the dry season.

\section{Introduction}

\subsection{The Amazon Forest climate}

The Amazon Forest spans more than $3000 \mathrm{~km}$ in the eastwest direction and approximately $2000 \mathrm{~km}$ from north to south. It crosses the Equator but is primarily located in the Southern Hemisphere and encompasses both equatorial and tropical climates. The northern expanse of the Amazon Basin is influenced by the tropical Atlantic Ocean, while the western edge is dominated by the Andes Mountains, which rise more than $4000 \mathrm{~m}$ a.s.l. (above sea level) in the tropical and equatorial regions.

Cavalcanti et al. (2009) have provided a detailed picture of weather and climate in Brazil, particularly in the Amazon. The dominant large-scale features in the Amazon are the lack of major temperature gradients and the absence of baroclinic weather systems. However, these features do not mean that there is a lack of convective organization. The main synoptic systems that approach the region and alter weather conditions are (a) the Intertropical Convergence Zone, mostly affecting the northern half of the Amazon; (b) the easterly waves coming from the tropical Atlantic (Diedhiou et al., 2010); (c) the upper tropospheric cyclonic vortices originating on the eastern coast of north-east Brazil and the associated upper-air Bolivian High (Silva Dias et al., 1983; Kousky and Gan, 1981); (d) the South Atlantic Convergence Zone, which affects the southern half of the Amazon and has a major effect on Amazonian convective activity as a whole (Rickenbach et al., 2002); and (e) the northward propagation of convective clouds (Siqueira and Machado, 2004) and the remnants of mid-latitude cold frontal systems that may propagate northward, sometimes beyond the Equator, resulting in so-called "friagem" events (Marengo et al., 1997). Within the basin, convection is often organized into squall lines (Cohen et al., 1995) that frequently occur as large systems originating at the northern coast and are triggered by local sea breeze circulation (Greco et al., 1994). Some of these squall lines propagate to Central Amazonas, dissipating during the night and reactivating the next day by diurnal heating.

Climate controls on Amazon Basin rainfall come from El Niño-La Niña episodes, which are defined by tropical Pacific Ocean sea surface temperatures (SSTs) and tropical Atlantic SSTs (Marengo et al., 2013, 2016). Warm tropical Atlantic SSTs are associated with drought conditions in the Amazon region. During El Niño episodes, most of the Amazon Basin experiences below-average rainfall, while during La Niña cases, the basin experiences above-average rainfall. The convective activity in most of the Amazon Basin is part of the South American monsoon system (SAMS), which is associated with distinct wet and dry seasons (Silva Dias and Carvalho, 2016).

Horel et al. (1989) used satellite downward longwave radiation to characterize seasonal variations in the Amazon and found that the region experiences typical wet and dry seasons each year, with two transition periods in between them. Machado et al. (2004) defined the driest month and the duration of the dry season regionally within the Amazon Basin. The dry season varies from only 1 month in the north-west to 3-4 months in south-eastern Amazonas. For the Central Amazonas region, July, August, and September are typically the driest months. Convection in Amazonas is more intense during the dry to wet transition season, during which thunderstorms exhibit more lightning activity (Albrecht et al., 2011) and are more sensitive to aerosol loading and topography (Gonçalves et al., 2015). The transition from the dry to wet season is influenced by complex interactions between smoke-derived aerosols and deep convective clouds (Albrecht et al., 2011). Although the seasonal variability in the average convective available potential energy (CAPE) is small, the tail of the CAPE seasonal distribution (computed as the surface parcel) exhibits relatively higher values during the dry to wet season transition than during the wet season (Williams et al., 2002). During the dry season, the aerosols produced by biomass burning in central South America impact a larger area, reaching the tropical Pacific, subtropical South America, and the South Atlantic (Andreae et al., 2001; Freitas et al., 2005, 2017; Camponogara et al., 2014).

While the Amazonas region exhibits strong seasonal variations in atmospheric circulation and related precipitation patterns, the diurnal cycle is typically the same throughout the year. Most of the region has an afternoon peak of convective activity; however, selected areas experience quite intense nocturnal systems and more pronounced seasonality (Saraiva et al., 2016). The diurnal convection cycle is strongly linked to underlying surface features (Machado et al., 2004; Silva Dias et al., 2002), including its topography (Laurent et al., 2002), deforestation (Saad et al., 2010), and large rivers (Dos Santos et al., 2014; Silva Dias et al., 
2004). Additionally, large rivers impact the evolution of rainfall through the convergence of river breezes with ambient air flow (Fitzjarrald et al., 2008). Adams et al. (2015) have shown that one central problem of the climate model related to the Amazon's diurnal convection and rainfall variability is the transition from shallow to deep convection, which occurs on a timescale of a few hours.

The evolution of the boundary layer in the Amazon region has been studied during intensive field observations conducted in different subregions in the Amazon Basin, including the Amazon Boundary Layer Experiment (ABLE 2A, 2B; see Harriss et al., 1988, 1990), the Anglo-Brazilian Amazonian Climate Observation Study (ABRACOS; see Gash et al., 1996), the Large-Scale Biosphere Atmosphere experiment in Amazonia (LBA; see Silva Dias et al., 2002), the Cloud Processes of the Main Precipitation Systems in Brazil: A Contribution to Cloud-Resolving Modelling and to the Global Precipitation Measurement (CHUVA; Machado et al., 2014) combined with ACRIDICON (Aerosol, Cloud, Precipitation, and Radiation Interactions and Dynamics of Convective Cloud Systems; Wendisch et al., 2016), and the Green Ocean Amazon GoAmazon2014/5 (Martin et al., 2017). Fisch et al. (2004) have indicated that the evolution of the boundary layer in the Amazon is linked to land cover and soil moisture, with a deeper mixed layer in the dry season over deforested areas and a shallower mixed layer over forested areas. During the wet season, there are small differences between the evolution of the mixed layer over forested and deforested regions.

During the dry season, the lower atmosphere is polluted by high aerosol concentrations caused by both biomass burning and prolonged aerosol suspension associated with reduced precipitation (Artaxo et al., 2002; Martin et al., 2010). During the wet season, the atmosphere is mostly clean and convective, and the landscape is referred to as the Green Ocean (Roberts et al., 2001; Williams et al., 2002; Andreae et al., 2004) because the convection there resembles storms over blue oceans, where the warm phase in clouds generally produces rain. Large urban areas, however, introduce perturbations into the pristine air (Martin et al., 2016, 2017).

The complex physico-chemical interactions observed in the Amazon Basin include rainfall formation processes, diurnal, seasonal, and inter-annual cycles, the spatial organization of clouds, the mechanisms controlling cloud condensation nuclei $(\mathrm{CCN})$, and the interactions between the vegetation, atmospheric boundary layer, clouds, and upper troposphere. These processes are all in perfect sync, resulting in a stable equilibrium climate that produces rainfall equivalent to $2.3 \mathrm{~m}$ throughout the 6.1 million $\mathrm{km}^{2}$ of the Amazon Basin, or the equivalent of an average 27 trillion metric tonnes of rainfall each year. However, this amazing, complex mechanism can be modified by human activities. A recent study illustrates and quantifies (Fu et al., 2013) how this stable environment can be disturbed and the point of equilibrium shifted far from the one that produces abundant fresh water, keeps the forest alive, and plays a primary role in controlling global atmospheric circulation and energy distribution.

\subsection{Knowledge about cloud process in the Amazon acquired during field campaigns}

The most recent GoAmazon2014/5 and CHUVAACRIDICON measurement campaigns established a comprehensive dataset to elucidate the complex aerosolcloud-precipitation interactions within the Amazon Basin. The GoAmazon observations, collected over 2 years, have delivered a wealth of data on aerosol-cloudprecipitation (ACP) interactions (Martin et al., 2016). During the two intensive operation periods (IOPs) conducted during the wet and dry seasons, additional airplane data were collected by the IARA (Intensive Airborne Research in Amazonas), Martin et al. (2017), and the ACRIDICON campaign (Wendisch et al., 2016). The data collected under the umbrella of the GoAmazon campaign also include the CHUVA project (Machado et al., 2014) and several other initiatives, which have compiled the most complete dataset in Amazonas associated with atmospheric chemical and physical interactions. GoAmazon2014/5 data were collected in the environs of Manaus city, the capital of Amazonas State. Manaus is a city of around 2 million people located in the middle of Central Amazonas and serves as a natural laboratory from which to explore the urban pollution effects on the Amazonas background environment.

Recent work by Gerken et al. (2015) has shown strong enhancement of ozone concentrations close to the surface during storm downdrafts in the central Amazon and suggests that storm downdrafts bringing higher ozone concentrations from middle to higher altitudes play an important role in enhancing ozone concentrations. The same effect was found by Betts et al. (2002) in the south-west Amazon during LBA. Wang et al. (2016) used airplane (G1) data to describe the mechanism by which aerosol concentrations are maintained in the pristine Amazonian boundary layer. Aerosol losses via precipitation scavenging at the surface are replaced by storm downdraft fluxes that bring high concentrations of nanosized particles from the upper atmosphere during precipitation events. These nanoparticles combine with the oxidation products of VOCs (volatile organic compounds) to form $\mathrm{CCN}$ at the surface and assist in the formation of clouds. Measurements by the G1 and by HALO (High Altitude and Long Range Research Aircraft) show a very high concentration of nanoparticles in the upper troposphere, with concentrations up to 65000 particles per $\mathrm{cm}^{3}$ (Andreae et al., 2017).

Aerosol particles influence cloud formation. Cecchini et al. (2016) have highlighted the effects of the Manaus aerosol pollution plume on cloud droplet size distribution during the wet season when only a small sensitivity would be expected. They describe the significant influence of the Manaus pollution plume in reducing the size and increasing the number of cloud droplets as well as the total liquid water con- 
tent. The ACRIDICON-CHUVA campaign collected in situ data during 14 research flights using the HALO research aircraft (Wendisch et al., 2016). The high number of flight hours inside growing cumulus clouds allowed for a sensitivity analysis of aerosol concentrations and the thermodynamic effects of such concentrations in the warm phase of cumulus clouds. Cecchini et al. (2017a) have also demonstrated that a $100 \%$ increase in aerosol concentrations led to an $84 \%$ increase in the concentration of droplets, but the same relative increase in vertical velocity corresponded only to a $43 \%$ change. Braga et al. (2017) have compared HALO microphysical probe measurements of cloud droplet concentrations with a parameterization based on $\mathrm{CCN}$ and updraft at the cloud base. Jäkel et al. (2017) have presented a new methodology to retrieve the vertical distribution of the hydrometeor phase using cloud-side reflected solar radiation measurements and have discussed the mixed-phase layer as a function of aerosol loading. Giangrande et al. (2016) have presented the statistical behaviour of vertical cloud motions as a function of season, instability, and convective inhibition. Burleyson et al. (2016) have discussed the diurnal cycle and spatial variability of deep convection among the different GoAmazon sites. Giangrande et al. (2017) have also presented an overview of cloud, thermodynamics, and radiation interactions.

Preceding GoAmazon2014/5, ABLE-2 and LBA collected cloud and rainfall data used to understand rainfall variability and its interaction with surface vegetation, topography, and aerosols in the Amazon. The ABLE-2 project consisted of two expeditions: the first in the Amazonian dry season (ABLE-2A) during July-August 1985 and the second in the wet season (ABLE-2B) during April-May 1987 (Harriss et al., 1988, 1990). Greco et al. (1990) have described the rainfall and kinematics of the central Amazon using GOES (Geostationary Operational Environmental Satellite) imagery, revealing the importance of tropical squall lines in the rainfall regime of the Amazon. Some years later, Garstang et al. (1994), Greco et al. (1994), and Cohen et al. (1995) provided a detailed description of tropical squall lines in the region. The TRMM-LBA campaign was designed to calibrate the TRMM (Tropical Rainfall Measuring Mission) satellite. The observations were conducted in southern Amazonas along the arc of deforestation during the wet season. Several studies contributed to our current understanding of rainfall variability at different scales. Machado et al. (2002) discussed the complex diurnal cycle interaction at a synoptic scale, while Laurent et al. (2002) examined the mesoscale convective system initiation and propagation, and Rickenbach (2004) showed the importance of nocturnal clouds in rainfall in south-western Amazonas. Silva Dias et al. (2002), Petersen and Rutledge (2001), and Cifelli et al. (2002) have all published findings using TRMM-LBA data to describe the microphysical properties of the rainfall field, cloud processes, and biospheric interactions in this region. In addition, different rainfall features have been de- tected associated with wind regimes; in particular, easterlies and westerlies in the southern Amazon have been associated with breaks and active phases of the South American monsoon system (Silva Dias and Carvalho, 2016; Rickenbach et al., 2002). In the north-western Amazon, northerlies and southerlies are associated with more stratiform and convective systems, respectively (Saraiva et al., 2016).

Other studies discuss the rainfall regime in Amazonas State. For example, Tanaka et al. (2014) have described the influence of the river and the city of Manaus in the diurnal cycle of rainfall using rain gauge data. Dos Santos et al. (2014) used satellite rainfall products to define the features of river breezes associated with the Negro, Solimões, and Amazon rivers. Fitzjarrald et al. (2008) have described the effect of the Tapajos River on rainfall, and Silva Dias et al. (2004) have shown how wind structure favours cloud formation on the upwind side of the Tapajós River during daytime. Negri et al. (2000) used passive microwave radiances to construct a 10-year climate related to the Amazonas rainfall patterns. Saraiva et al. (2016) have described the general statistics related to Amazonas rainfall using the meteorological S-band radar operational network and have discussed the diurnal cycle as well as the relationship between reflectivity and the cloud electrification process.

All of these studies have contributed to the establishment of our basic knowledge about the rainfall statistics and related processes in Amazonas; they have provided a new perspective for research in Amazonas and have elucidated several aspects of ACP interactions. The studies associated with field campaigns covered specific seasons (normally the wet season) or resulted from sparse rain gauge or indirect measurement data with low spatial and temporal resolutions. In GoAmazon2014/5, the extensive rainfall dataset collected using the S-, X-, and W-band radars, airplanes, disdrometers and vertical-pointing radar, rain gauges, microwave radiometers, ceilometers, and lidar provides a comprehensive view of the main variables and characteristics of precipitation in the central Amazon.

Giangrande et al. (2017) present an overview of cloud aspects that primarily focuses on the diurnal cycle and its impact on the radiative and thermodynamic effects of clouds. This study presents an overview of the rainfall characteristics and sensitivities to vegetation, topography, and aerosol particles and evaluates the seasonal variability of these factors. The main goal is to discuss the sensitivities of the primary processes controlling rainfall over the central Amazon using a relatively long time series (2014-2015) of data based on a comprehensive dataset collected during GoAmazon2014/5 and complemented by aircraft measurements made during ACRIDICON-CHUVA.

Section 2 describes the data and methodology employed in the study. Section 3 presents the results and discussions of the seasonal rainfall characteristics and sensitivities to aerosol, vegetation, and topography, and Sect. 4 summarizes the major findings. 


\section{Data and methodology}

Several instruments were employed in this study. This section describes the instruments and the data processing procedures. Figures 1 and 2 in the Martin et al. (2016) study show the GoAmazon site locations and the flight tracks of the G1 aircraft. Wendisch et al. (2016) show the flight tracks (Fig. 6) of the HALO aircraft during the ACRIDICONCHUVA campaign.

A laser precipitation disdrometer (PARSIVEL; see Löffler-Mang and Joss, 2000) measures the size and terminal velocity of hydrometeors that pass through the detection area sampled by a laser beam $\left(54 \mathrm{~cm}^{2}\right)$ over a specific time interval. Two different PARSIVEL disdrometers were used during the entire campaign: one during the CHUVA project from January to September 2014 and another, the ARM (Atmospheric Radiation Measurement), from September 2014 to October 2015. Raindrops larger than $5 \mathrm{~mm}$ were eliminated from the dataset to best match the co-located rain gauge accumulated rainfall, and a complementary filter was applied as described by Giangrande et al. (2016). The drop size distribution (DSD) and all respective rainfall rates (RRs, in $\mathrm{mm} \mathrm{h}^{-1}$ ) and mass-weighted mean diameters $\left(D_{\mathrm{m}}\right.$, in $\left.\mathrm{mm}\right)$ were obtained in $5 \mathrm{~min}$ intervals for periods during which $\mathrm{RR} \geq 0.5 \mathrm{~mm} \mathrm{~h}^{-1}$, as suggested by Tokay et al. (2013).

The Doppler radar S-band dataset consists of retrievals from the Manaus radar operated by the Amazon Protection System (SIPAM). The reflectivity and RR fields were computed using the $2.5 \mathrm{~km}$ SIPAM Manaus S-band Constant Altitude Plan Position Indicator (CAPPI) for each radar volume at $10 \mathrm{~min}$ intervals. The corrected radar reflectivity for each volume was interpolated to a fixed grid on which the rainfall products were generated. Specific procedures were applied to the dataset to compute RRs from reflectivity, reduce noise, and improve data quality. First, RRs were computed using a $Z-R$ relationship adjusted to the region using 2014 wet season impact disdrometer data: $Z=174.8 R^{1.56}$. This is a fixed $Z-R$ relationship for convective and stratiform clouds and for both the wet and dry seasons. Therefore, the total rainfall estimated should be considered a reference by which to study the differences among the topography and vegetation classes and not as an absolute, precise rainfall amount. The maximum and minimum RRs considered were 160 and $0.5 \mathrm{~mm} \mathrm{~h}^{-1}$, respectively. The RR was not computed when the radar beam had less than $10 \%$ quality reflectivity values (non-null reflectivity). Finally, a range filter was applied to remove pixels closer than $10 \mathrm{~km}$ and farther than $135 \mathrm{~km}$ from the radar.

The Doppler radar X-band dual-polarization dataset was obtained by the mobile Meteor 50DX Selex radar during the CHUVA project (Schneebeli et al., 2012). The radar data underwent three main processing steps, including differential phase shift (PhiDP) filtering and specific differential phase (KDP) derivation, differential reflectivity (ZDR) offset correction, and horizontal reflectivity (Zh) and ZDR attenu-

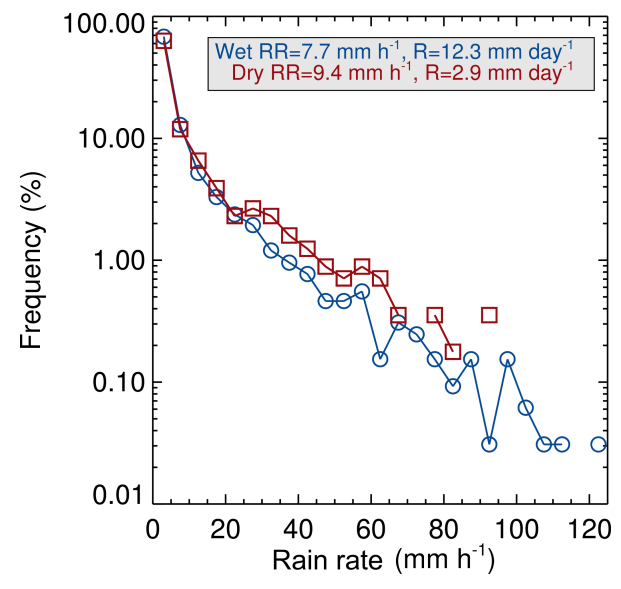

Figure 1. Rainfall rate (RR) histogram for wet and dry seasons computed using the T3 disdrometer. Wet and dry seasons occurred from January to March and August to October, respectively, for the years 2014 and 2015. Rainfall rate (RR) and total rainfall (R) are given in the legend.

ation correction. The uncorrected raw differential phase shift had a noisy signal that required filtering and smoothing before its range derivative (KDP) could be calculated. Several methods were available for use, such as a moving average, median filters, and linear programming approaches. In this study, we used the finite impulse response (FIR) filter based on Hubbert and Bringi (1995). Once the filtered PhiDP profile was obtained, KDP was calculated using a least squares linear fit. To verify and calibrate the accuracy of the differential reflectivity measurement, a vertical-pointing rotating scan (also known as "bird-bath" scan) was incorporated into the X-band scan strategy. During light precipitation and in the absence of strong winds, the vertical and horizontal return signals of a vertically oriented beam should be the same. Differences between the horizontal and vertical channels may appear due to poor calibration between the channels, random effects, beam-filling, or side-lobe clutter contamination, among other factors (Gorgucci et al., 1999). Although standard calibration was performed, careful examination of the ZDR behaviour before and after the calibration was necessary. We selected all of the observations with no radar gates higher than $30 \mathrm{dBZ}$ below $2 \mathrm{~km}$ and analysed the overall ZDR values and temporal changes in the mean value. A persistent, positive ZDR offset (approximately $0.5 \mathrm{~dB}$ ) was found and applied to the data. After these steps, we applied an attenuation correction. X-band radars are more prone to signal attenuation due to rain than $\mathrm{C}$ - and $\mathrm{S}$-band radars. It is therefore mandatory to correct the signal for attenuation prior to any analysis using reflectivity data if such a correction is possible (Schneebeli et al., 2012). With a dual-polarization system, one can use the differential phase shift to calculate the attenuation due to rain. We applied the ZPHI method (Testud et al., 2000) to the entire dataset for which dualpolarization moments were available. The corrected $\mathrm{Zh}$ and 

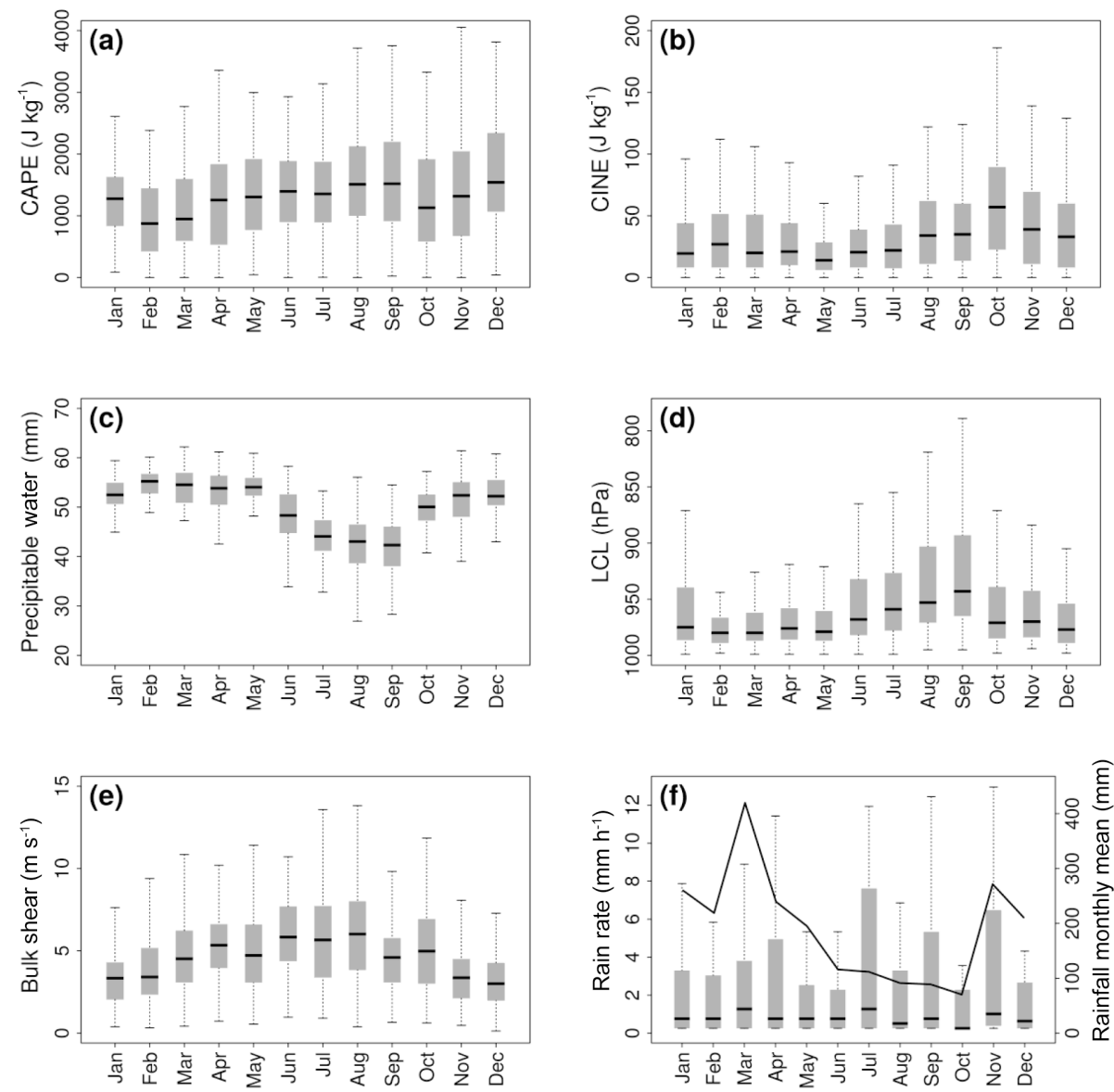

Figure 2. Box plots illustrating monthly (a) convective available potential energy (CAPE), (b) convective inhibition energy (CINE), (c) precipitable water vapour (PWV), (d) lifting condensation level (LCL), (e) bulk shear, and (f) mean rainfall rate (RR) and rainfall. Data are for 2014 and were collected at 00:00, 06:00, 12:00, and 18:00 UTC using the T3 radiosondes. Rainfall was computed using the T3 rain gauge. Each box represents the 25 to $75 \%$ populations and the line inside the box shows the median value.

ZDR values were then ready to be used as inputs for rainfall analyses or hydrometeor classification studies.

The cloud droplet size distributions were derived from the HALO measurements using a cloud droplet probe (CDP; Lance et al., 2010; Molleker et al., 2014; Wendisch and Brenguier, 2013). This instrument measures the droplet size distribution within the size range of 3 to $50 \mu \mathrm{m}$ based on the hydrometeor's forward-scattering properties. The DSD is sorted into 15 size bins for each measurement cycle. The probe was operated at a $1 \mathrm{~Hz}$ frequency. The major sources of uncertainty for the instrument are as follows (Weigel et al., 2016): (a) uncertainty in the cross-sectional area $\left(0.278 \mathrm{~mm}^{2} \pm 15 \%\right)$, (b) the relatively small sample volume (cross-sectional area multiplied by aircraft speed), and (c) counting statistics for each size bin. As noted by Molleker et al. (2014), the CDP uncertainty is approximately $10 \%$. Braga et al. (2017) performed a comparison between the CDP and the other HALO cloud probes and concluded that they agree within instrumental uncertainties. The vertical wind component $(w)$ was measured by the Basic HALO
Measurement and Sensor System (BAHAMAS) located at the nose of the aircraft (Wendisch et al., 2016) and calibrated according to Mallaun et al. (2015). The uncertainty in $w$ is approximately $0.3 \mathrm{~m} \mathrm{~s}^{-1}$.

Using the disdrometer or the CDP, the mass-weighted mean diameter $\left(D_{\mathrm{m}}\right)$ was computed as the ratio between the fourth and third moments (liquid water content) of the DSD (see Bringi et al., 2002, for a detailed description). For every $5 \mathrm{~min}$ of a continuous rainfall event (defined as $\mathrm{RR} \geq 0.5 \mathrm{~mm} \mathrm{~h}^{-1}$ ), the moments were computed using a parameterization derived by Tokay and Short (1996).

A condensation particle counter (CPC, TSI 3010) in the aerosol observing system instruments from ARM measured the concentration of individual aerosol particles at $10 \mathrm{~m}$ a.g.l. at the T3 site (main GoAmazon site at Manacapuru; see Martin et al., 2016, for a detailed description). The data were averaged to $5 \mathrm{~min}$ intervals covering the period from January 2014 to March 2015 (Thalman et al., 2017). Background or polluted conditions were defined based on the specific CPC distribution for each season by the thresh- 
old value associated with the 33 and $66 \%$ percentile, respectively, for the dry and wet seasons. The threshold values and details are presented in the relevant sections below.

The total concentration of individual cloud condensation nuclei particles $\left(N_{\mathrm{CCN}}(S)\right)$ was measured with a continuousflow stream-wise thermal gradient CCN counter (model CCN-200, DMT, Longmont, CO, USA; Rose et al., 2008). The measured aerosol was sampled by the HALO aerosol submicrometer inlet (HASI). Particles with a critical supersaturation $(S=0.52 \pm 0.05 \%)$ were activated and formed water droplets. Water droplets with a diameter $\geq 1 \mu \mathrm{m}$ were detected by an optical particle counter. Details about the measurement mode can be found in Andreae et al. (2017). The error in supersaturation resulted from the calibration uncertainty, as described by Pöhlker et al. (2016); it is estimated to be in the range of $10 \%$.

This study considers the wet and dry seasons as the months of January to March and August to October, respectively. Some instruments operated only during the two GoAmazon2014/5 IOPs: IOP1 during the wet season and IOP2 during the dry season. IOP1 corresponds to February to March and IOP2 to 15 September to 15 October 2014. The S-band radar data are available for both years (2014 and 2015), while the X-band operated only in the 2014 IOPs.

Thermodynamic parameters such as CAPE, convective inhibition energy (CINE), precipitable water vapour (PWV), lifting condensation level (LCL), and bulk shear were computed using the $\mathrm{T} 3$ radiosondes at 00:00, 06:00, 12:00, and 18:00 UTC for 2014. The thermodynamic parameters were computed using temperature and humidity at the surface. Bulk shear is defined as the difference between the average surface $6 \mathrm{~km}$ wind velocity and the surface $500 \mathrm{~m}$ wind velocity.

\section{Results and discussion}

This section first discusses the rainfall characteristics and variability by comparing the wet and dry seasons to establish the primary differences between seasons. Section 3.2 discusses the sensitivity analyses relative to aerosols, vegetation, and topography.

\subsection{Rainfall seasonal variability}

Seasonal variability was analysed from different perspectives, including general patterns, regional differences, satellite (clouds) and radar (rainfall) observation characteristics, DSD, rainfall vertical profile, and hydrometeor populations.

\subsubsection{General precipitation and thermodynamic patterns}

Amazonas has a distinct seasonal variability with distinct wet and dry seasons. The length and start date of the wet season depends on the location within the Amazon Basin. The mean monthly rainfall (2014-2015) was $369 \mathrm{~mm}$ for the wet season (considering a month of 30 days) and $87 \mathrm{~mm}$ for the dry season. These numbers show the large difference expected between the two seasons. However, the RR (considering only when raining) also exhibited seasonal differences. The mean $\mathrm{RR}$ (computed in $5 \mathrm{~min}$ intervals) for the wet season was $7.7 \mathrm{~mm} \mathrm{~h}^{-1}$, while that for the dry season was $9.4 \mathrm{~mm} \mathrm{~h}^{-1}$. Therefore, although approximately 4 times less accumulated rainfall was recorded during the dry season than the wet season, the average rainfall event during the dry season produced a greater amount of rain. Figure 1 reveals this feature: the relative rainfall rate distribution for the wet season shows a higher relative frequency for $\mathrm{RR}<20 \mathrm{~mm} \mathrm{~h}^{-1}$ than that of the dry season. On the other hand, the dry season shows a higher relative frequency for $\mathrm{RR}>20 \mathrm{~mm} \mathrm{~h}^{-1}$. There was only one event during the wet season in which a record $R R$ of approximately $100 \mathrm{~mm} \mathrm{~h}^{-1}$ was recorded within a few minutes. The relative intensity of dry season rainfall events is more pronounced than that of events during the wet season. This distinctive feature has important consequences for the microphysical and macrophysical structures of clouds. The main reason for this difference is associated with instability and cloud cover. Figure 2 presents monthly box plots for the thermodynamics variables, with the lower $\left(Q_{1}\right)$ and upper $\left(Q_{3}\right)$ bounds representing the 25 and 75 percentiles. The whiskers are defined by $Q_{1}-1.5 \cdot \mathrm{IQR}$ (lower) and $Q_{1}+1.5 \cdot \mathrm{IQR}$ (upper); IQR is the interquartile range $\left(Q_{3}-\right.$ $Q_{1}$ ).

Figure 2a shows the CAPE distribution for the wet and dry seasons in 2014. The dry season has a larger CAPE than the wet season, and the frequency with which the CAPE exceeds $2000 \mathrm{~J} \mathrm{~kg}^{-1}$ is higher during the dry season. The wet season has typical monsoonal rainfall with widespread moderate rain in contrast to the more isolated and intense rainfall events that occur during the dry season. The Zhuang et al. (2017) study of the shallow to deep convection transition in Amazonas found similar results.

This characteristic of rainfall events in which a higher RR occurs during dry season rainfall events is explained by the seasonal differences in the thermodynamic parameters. Figure 2 highlights some of these important differences. The dry season has a larger CAPE, higher CINE, less available water vapour, a higher cloud base, and higher shear than the wet season. The CAPE increases from March to September, and the largest tail distributions occur at the end of the year when humidity increases and cloud base decreases. During the dry season, only regions with strong forcing can produce convective clouds that use the higher CAPE and shear available to produce organized convection. Gonçalves et al. (2015) show that increased RRs (radar reflectivity values larger than $35 \mathrm{dBZ}$ ) during the dry season mainly occur over higher elevations in Amazonas (Sect. 3.2.1). The higher CINE and smaller amount of water vapour reduces the occurrence of convection, but when convection is able to develop, it has all the ingredients to be deeper. Machado et al. (2004) explain 
(a) RADAR SIPAM: reflectivity $\geq 20 \mathrm{dBZ}$

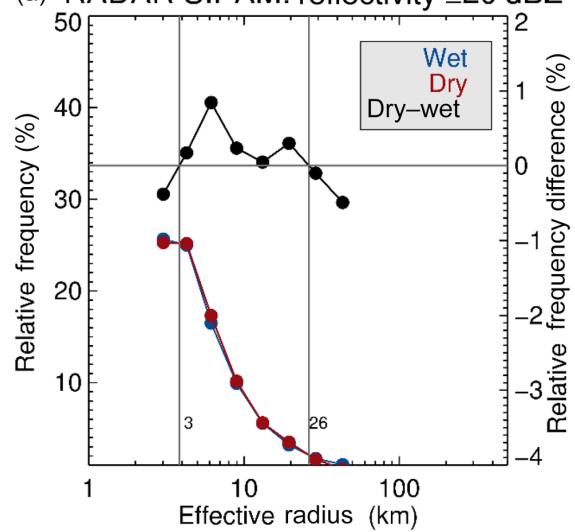

(b) Satellite GOES: BT $\leq 235 \mathrm{~K}$

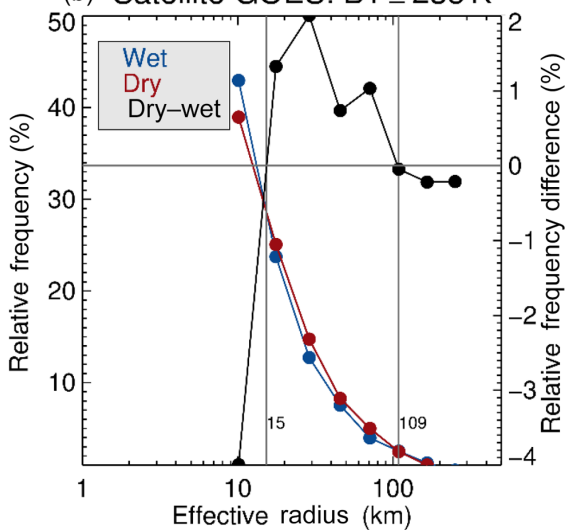

Figure 3. Rain cell (a, based on the SIPAM S-band radar) and cloud cluster (b, based on GOES-13 IR brightness temperature; $B_{T}$ ) size distributions between wet and dry seasons and the difference between dry and wet season distributions.

that the more intense convective clouds during the dry to wet season transition may result from less competition of surface moisture convergence to feed cumulonimbus clouds because a smaller number of rain cells exist. Figure $2 \mathrm{f}$ presents the RR statistics for 2014 and the monthly rainfall measured by rain gauge in $\mathrm{T} 3$.

\subsubsection{Size distribution of cloud clusters and rain cells}

Cloud clusters and rain cell data were derived from GOES-13 satellite images and S-band radar using the ForTraCC (Forecasting and Tracking Cloud Clusters; see Vila et al., 2008) algorithm. A cloud cluster is defined by connected ensembles of pixels with brightness temperatures $\left(B_{T}\right)$ for the $10.5 \mu \mathrm{m}$ channel that are colder than $235 \mathrm{~K}$, as defined by Machado et al. (1998). A rain cell is defined as a connected ensemble of pixels in the radar $2.5 \mathrm{~km}$ CAPPI with reflectivity larger than $20 \mathrm{dBZ}$. Quite often, rain cells, which are embedded in cloud clusters, are observed when clouds start to form raindrops. The average cloud cluster size and lifespan are a $75 \mathrm{~km}$ effective radius (hereafter called radius) and $1.5 \mathrm{~h}$, respectively, during the wet and dry seasons in the Amazon. The typical rain cell has a $7.5 \mathrm{~km}$ radius and a $0.6 \mathrm{~h}$ lifespan. On average, cloud clusters are 10 times larger and have lifespans of approximately 3 times that of their associated rain cells. These are average characteristics; cloud clusters come in a wide range of sizes. Cloud clusters can exceed $300 \mathrm{~km}$ in radius and have a lifespan longer than $24 \mathrm{~h}$, while rain cells can grow to up to approximately $60 \mathrm{~km}$ in radius and last for a couple of hours. Figure 3 shows the dry and wet season cloud clusters and rain cell size distributions identified in this study, as well as the differences between them. The basic size distribution does not vary substantially between the two seasons because cloud cluster size distribution follows an exponential distribution, as shown by Machado et al. (1992); however, certain distinctions can be noted if the difference is computed. The wet season has more small and large rain cells and cloud clusters than the dry season. The dry season produces more rain cells in the range of a $10 \mathrm{~km}$ radius and cloud clusters of an approximately $40 \mathrm{~km}$ radius. The ratio between the cloud cluster and rain cell average radii during the wet season is much greater because of the larger stratiform cloud decks typical of a monsoon cloud regime. The thermodynamics of the dry season environment discussed in the preceding section favour the organization of more compact and active convection with more intense rainfall events but accumulated rainfall amounts that are 4 times smaller.

\subsubsection{Mass-weighted mean rainfall diameter for the dry and wet seasons}

Variations in cloud processes between the two Amazonian seasons were evaluated in this study in order to determine whether important microphysical differences between raindrops during the wet and dry seasons exist or whether only $R R$ and rainfall frequency vary between seasons. These features were investigated through the deployment of disdrometers and a dual-polarimetric radar. This study focuses on rainfall and raindrops; however, seasonal differences in cloud droplet size distributions may warrant attention as well.

For instance, the effect of aerosol concentrations on cloud droplets in shallow convective clouds, where aerosols generally reduce the size and increase the concentration of a given liquid water content, is well known (Cecchini et al., 2016, among several other studies). However, if a polluted cloud transitions from shallow to deep convection, aerosols can invigorate clouds (Rosenfeld, 2008; Koren et al., 2012; Gonçalves et al., 2015). Giangrande et al. (2017) present the G1 airplane cloud particle distribution measurements taken during GoAmazon2014/5 and show the predominance of larger cloud droplets in warm clouds during the wet season. The in situ cloud droplet data were collected for a shallow cloud population. The result is very different when seasonal data collected using disdrometers that measure raindrops at 
least 100 times larger (measured as mass-weighted mean diameter; $D_{\mathrm{m}}$ ) are compared. Given that raindrop diameter depends on RR, which varies between the two seasons, dry and wet season $D_{\mathrm{m}}$ values were compared as a function of RR in $5 \mathrm{~mm} \mathrm{~h}^{-1}$ intervals. Different frequencies of convective and stratiform clouds during the wet and dry seasons also merit evaluation. As discussed by Giangrande et al. (2017), stratiform clouds occur more often in the wet season than the dry season; hence, $D_{\mathrm{m}}$ should be evaluated separately for convective and stratiform clouds. The cloud classification employed in this study was performed using the radar wind profiler (RWP) and ancillary data as described by Giangrande et al. (2017) from March 2014 to December 2015. Clouds were classified based on the predominant cloud type in the warm cloud layer. Convective clouds include strong and weak convection, while stratiform clouds include those with and without a well-defined bright band.

Figure $4 \mathrm{a}$ and $\mathrm{b}$ show the $D_{\mathrm{m}}$ values for the wet and dry seasons as functions of the RR for convective and stratiform clouds. The arrows on the $x$ axis mark distributions for which the averages vary given a statistical significance of $95 \%$. For convective clouds, the mass-weighted mean diameter is larger during the dry season for a given RR. This result suggests that the different cloud processes generate larger rainfall drops. The differences in shallow clouds during the dry season may be due to the reduced humidity, as shown in Fig. 2c, which can reduce supersaturation and increase droplet evaporation via entrainment. However, if a cloud evolves into the deep convective stage, the higher cloud base, shear, and CAPE induce stronger vertical motion and mesoscale organization, generating higher quantities of ice (shown in the next section) and forming larger raindrops through the melting of large ice particles such as snow and graupel. For stratiform clouds (Fig. 4b), the difference between the two seasons is much smaller and significant only for very low RRs.

\subsubsection{Cloud vertical profiles for the dry and wet seasons}

The results presented above discuss rainfall at the surface level. To better understand the cloud processes associated with the dry and wet seasons we must evaluate the hydrometeor vertical profiles of precipitating clouds. An Xband dual-polarization radar was installed at the T3 site and operated during the GoAmazon2014/5 IOPs in FebruaryMarch and September-October 2014. To account for potential wet radome attenuation effects and obtain useful dualpolarization measurements with sufficient vertical coverage, the data analysed included only cases without rain over the radar and collected within the 10 and $60 \mathrm{~km}$ radius range. As described in the methodology section, the volume scan was processed with attenuation correction and a ZDR offset to build contoured frequency by altitude diagrams (CFAD) of reflectivity $(Z)$, specific differential phase (KDP), differential reflectivity (ZDR), and the horizontal and vertical corre-
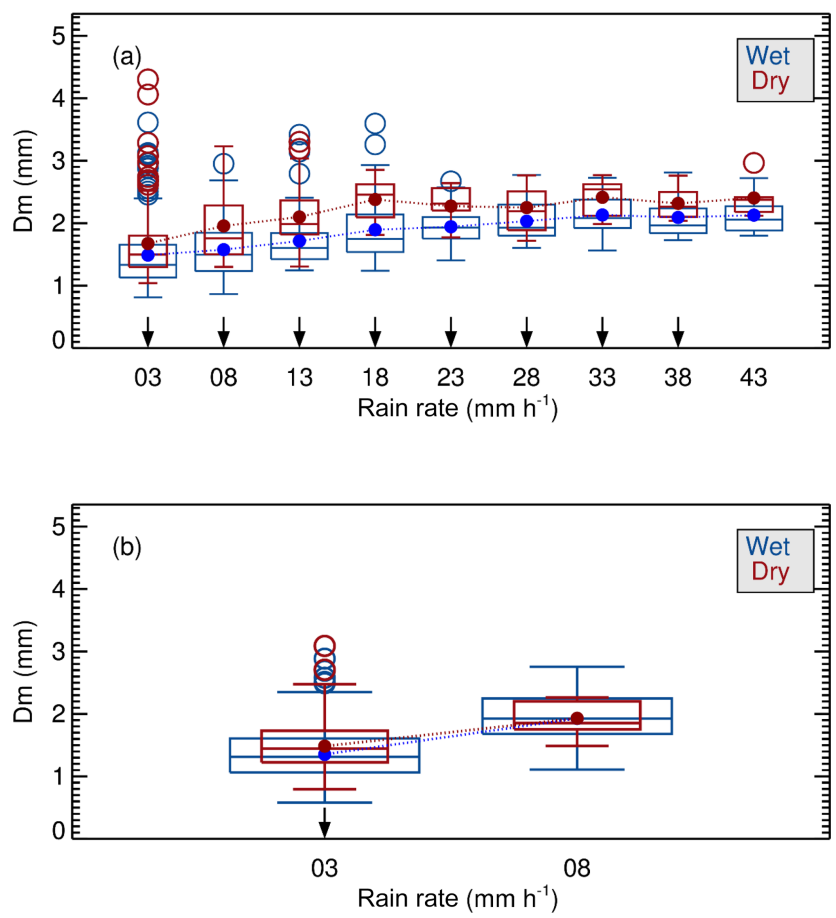

Figure 4. Mass-weighted mean raindrop diameter $\left(D_{\mathrm{m}}\right)$ as a function of the rainfall rate (RR) for wet and dry seasons for (a) convective and (b) stratiform rain events. The arrows on the $x$ axis indicate variations in the averages based on the Student's $t$ test (95\% confidence). The box represents the 25 to $75 \%$ populations and the line inside the box shows the median value; the circles are the outliers.

lation coefficient for the consistency of the $H$ and $V$ returned power and phase of each pulse for both the wet and dry seasons.

Figure 5 shows the reflectivity CFAD for the wet and dry seasons. The typical stratiform and convective patterns for the wet and dry seasons are clearly visible. For the wet season, the bright band is very clear and has a pronounced peak at approximately $4 \mathrm{~km}$, which corresponds to the layer in which ice melts and reflectivity increases. Moreover, the levels above the melting layer have less intense reflectivity, demonstrating the less intense convective process that occurs in the majority of cases during the wet season. For the dry season, the typical convective profile with a higher reflectivity in the lower levels corroborates the higher RRs observed during this season. In addition, the mixed and glaciated layers exhibit more frequent high reflectivity values, indicating the presence of large ice hydrometeors.

Figure 6 shows the CFAD for the dual-polarization parameters, ZDR, KDP, and co-polar correlation coefficient. The hydrometeor response to the transmitted signal depends on several factors that may alter certain characteristics of the measured signal, such as hydrometeor orientation by the electrification field (see Mattos et al., 2017, for a detailed discussion), ice density, and crystal shape. Of course, there 


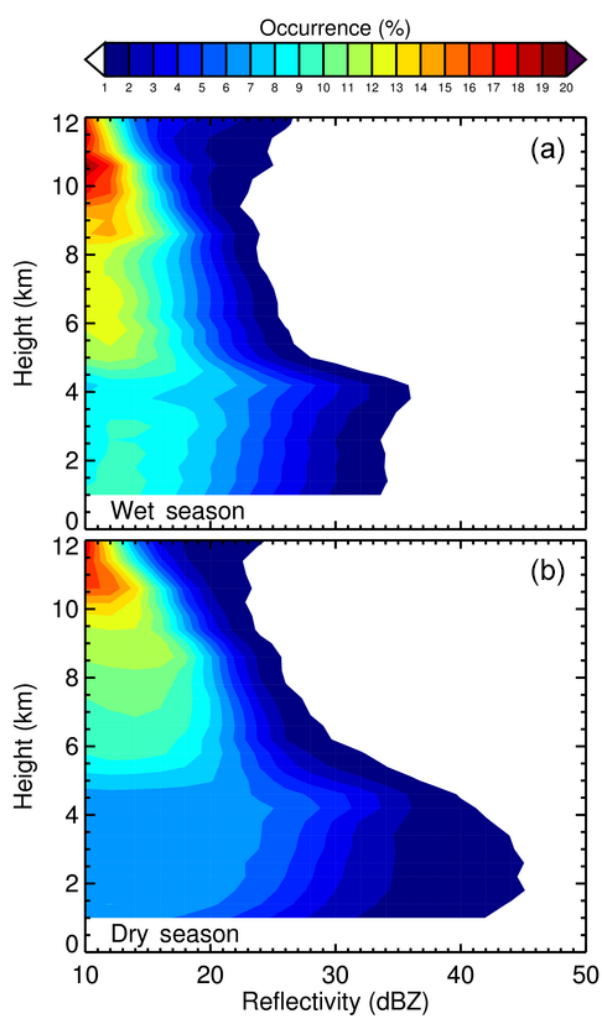

Figure 5. X-band radar reflectivity contoured frequency by altitude diagram (CFAD) for the wet (a) and dry (b) seasons. Each CFAD consists of a PDF of reflectivity ( $2 \mathrm{dBZ}$ bin intervals) at each height (400 $\mathrm{m}$ bin intervals) multiplied by 100 so that values are displayed as a percentage.

are also other possible effects that may impact the data quality, such as resonance and partial beam-filling. Although the CFADs are not completely different, given that these parameters have a small range of variation and are subject to the limitations described above, some clear seasonal differences can be observed. The ZDR that largely reflects ice orientation contains a greater number of near-zero or negative signals during the dry season compared to the wet season. This is likely associated with crystal orientation by the electrical field as more lightning occurs (see Williams et al., 2002), and more vertically oriented ice shapes such as graupel may occur during the dry season than the wet season. The KDP distribution shows considerably larger values in the warm layer during the dry compared to the wet season, indicating that the higher RRs and greater number of positive values in the mixed phase are probably associated with intense updrafts, as shown by Giangrande et al. (2016). The correlation coefficient highlights an interesting feature. During the dry season, there appears to be a clearer distinction between the mixed phase and the glaciation phase above $8 \mathrm{~km}$. The wet season correlation coefficient is more homogenous with height inside the cloud. Cecchini et al. (2017b) and Jäkel et al. (2017) discuss the greater efficiency of clouds forming in a clean environment to produce ice. The dry season exhibits higher average correlations at approximately $8 \mathrm{~km}$, demonstrating a deeper and unmixed water layer at these heights. This likely indicates that clouds forming during the wet season have a smaller mixed phase than clouds forming during the dry season and under poor air quality conditions.

\subsection{Rainfall sensitives to aerosols, topography, and vegetation}

This section presents rainfall sensitivities to different surface types, topography, and aerosol concentrations. Ancillary data describing vegetation type, topography, and aerosol concentrations, as well as measurements from the HALO airplane are employed to study the total rainfall, RR, cloud droplet, and raindrop sensitivities to these environmental and geographic characteristics.

\subsubsection{Rainfall $D_{\mathrm{m}}$ as a function of rainfall rate for polluted and clean cases}

The impact of aerosol concentration on cloud microphysical properties needs to be analysed for the different seasons. Particle concentrations measured at the surface using the CPC during the dry and wet seasons vary greatly from one another. For instance, the 33rd and 66th percentiles are 673 and $1377 \mathrm{~cm}^{-3}$ for the wet season and 1954 and $3392 \mathrm{~cm}^{-3}$ for the dry season, respectively. Nearly 3 times as many aerosols are present during the dry compared to the wet season, which can have substantial implications for cloud and rainfall formation. However, as shown in Fig. 2, the thermodynamic characteristics also vary greatly, and the differences cannot be explained only by the difference in aerosol concentrations. To evaluate the impact of aerosols on cloud processes, the mass-weighted mean rainfall diameter must be evaluated for different particle concentrations during each season. However, after analysis, this comparison was only possible during the wet season because rainfall events with particle concentrations exceeding the 66th percentile in the dry season were rare. During the dry season, the upper one-third of aerosol concentrations are characterized mostly by drier days. The dry season is characterized by biomass burning and approximately 6 times more mass-loaded (organic) aerosols than during the wet season. Shilling et al. (2018) describe the typical aerosol types and the evolution of organic aerosol particles during the wet and dry season in the Manaus pollution plume. Figure 7 shows the $D_{\mathrm{m}}$ during the wet season for background (particle concentrations less than the 33rd percentile) and polluted (particle concentrations greater than the 66th percentile) conditions as a function of RR. This calculation requires two different instruments to be co-located. Therefore, the number of samples from each 5 min continuous rainfall event interval in each RR class was drastically reduced. Consequently, the differences between the two air quality categories in each RR bin were significant only at the 

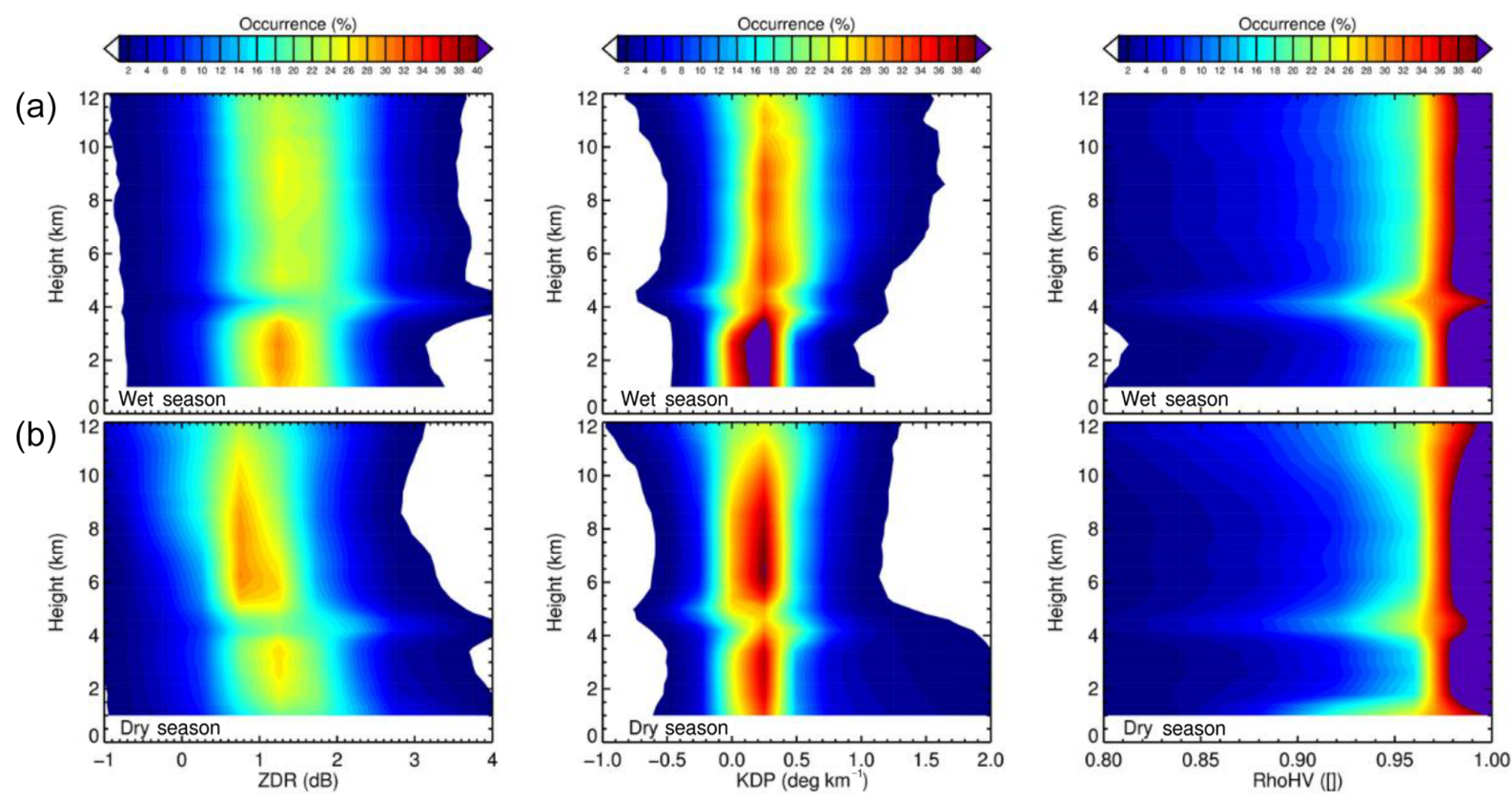

Figure 6. ZDR (gives an idea of horizontal-positively and vertical-negatively oriented hydrometeors), KDP (gives an idea of hydrometeor concentration and hydrometeor orientation), and horizontal-vertical correlation (gives an idea of the homogeneity of the hydrometeor) contoured frequency by altitude diagram (CFAD) for the wet (a) and dry (b) seasons as derived using the X-band radar. Each CFAD consists of a PDF of ZDR ( $0.5 \mathrm{~dB}$ bin intervals), KDP ( $0.5 \mathrm{~dB}$ bin intervals), and co-polar correlation ( 0.05 bin intervals $)$ at each height ( $400 \mathrm{~m}$ bin intervals) multiplied by 100 so that the values are displayed as a percentage.

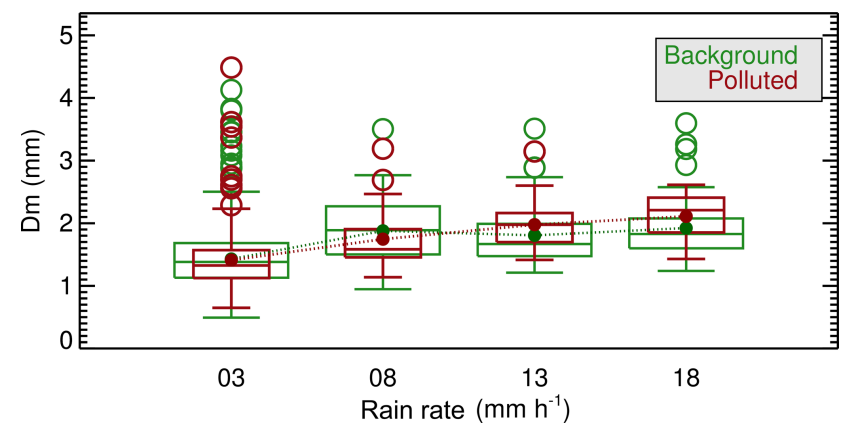

Figure 7. Mass-weighted mean rainfall diameter as a function of the rainfall rate $(\mathrm{RR})$ during the wet season for clean $(\mathrm{CPC}$ smaller than the 33rd percentile) and polluted (CPC larger than the 66th percentile) air over the T3 site. Each box represents the 25 to $75 \%$ populations, and the line inside the box shows the median value; circles represent outliers.

$85 \%$ level. Even if the differences between the two average values for background and polluted cases are not significant, the physical results show clear trends. For low RRs, which are more often associated with warm cloud processes, the cases with background aerosol concentrations have a larger $D_{\mathrm{m}}$ because there are fewer CCN and lower cloud droplet concentrations, resulting in large raindrops. However, for greater RRs, which are typically associated with deep convection, the $D_{\mathrm{m}}$ is greater for polluted clouds, demonstrating the major effect of convective invigoration discussed in the preceding section. Rosenfeld and Ulbrich (2003) used satellite data to estimate raindrop size distributions for continental and maritime Amazon clouds (LBA). They found that clouds over the continent produce greater concentrations of large drops and smaller concentrations of small drops. They suggested that this behaviour is caused by the effects of aerosols on precipitation formation processes.

\subsubsection{Rainfall sensitivity to surface cover}

There is a very complex diurnal cycle over the Amazonas basin. Burleyson et al. (2016) used 15 years of satellite data to show a heterogeneous spatial distribution of convection that results from numerous local effects of rivers and vegetation cover. Using radar data, Saraiva et al. (2016) also found the Amazonas diurnal cycle to vary regionally. In addition to the natural geographic effect, rainfall modulation occurs through anthropogenic-induced changes in vegetation and the presence of large cities. Durieux et al. (2003) have shown that cloud cover varies as a function of the deforestation pattern. Lin et al. (2010), among several other studies, have discussed the urban heat island effect on the region's climate. To understand how vegetation cover influences precipitation characteristics, two approaches were applied: one using statistical radar data and the other using a special HALO mission specifically aimed at this topic. 
(a)

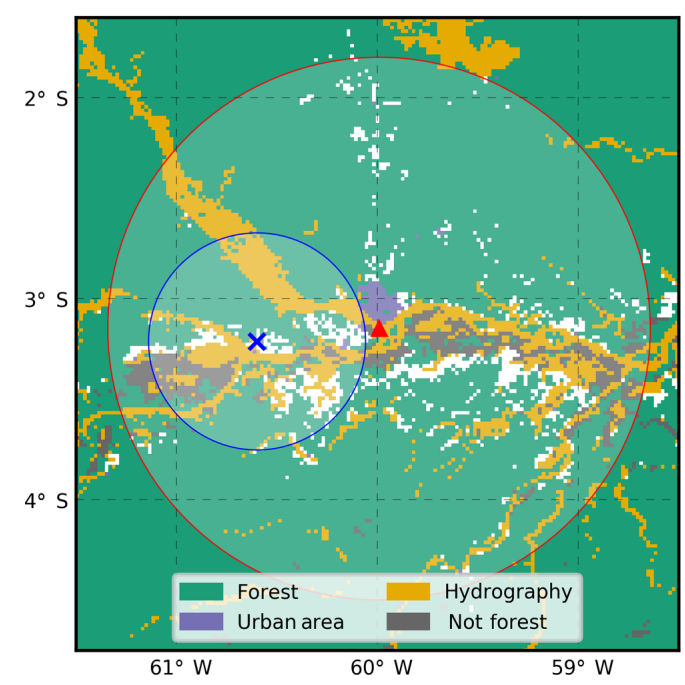

(b)

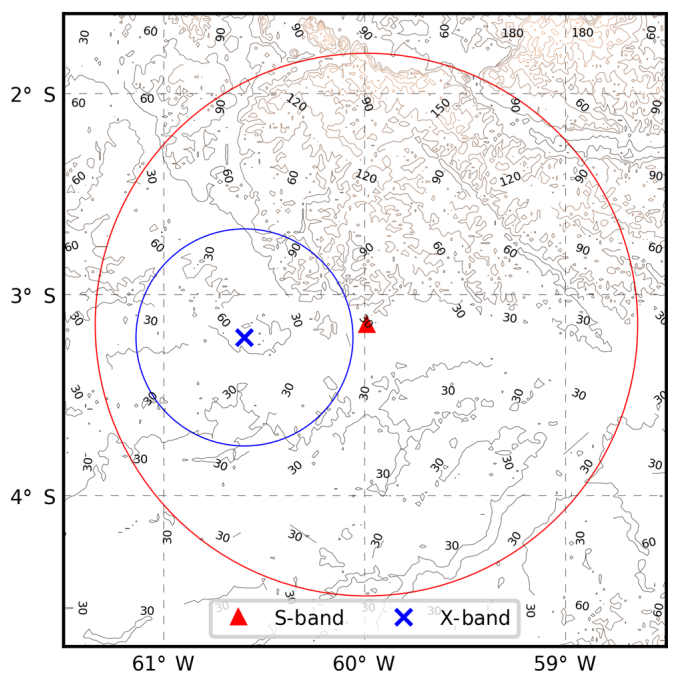

Figure 8. (a) Four vegetation classes as obtained from the digital Terra Class classification: forest, hydrography, non-forest, and urban area. (b) Topography across a $150 \mathrm{~km}$ radius as derived using SIPAM radar. X-band (T3 site) and S-band radar positions are shown in the figure.

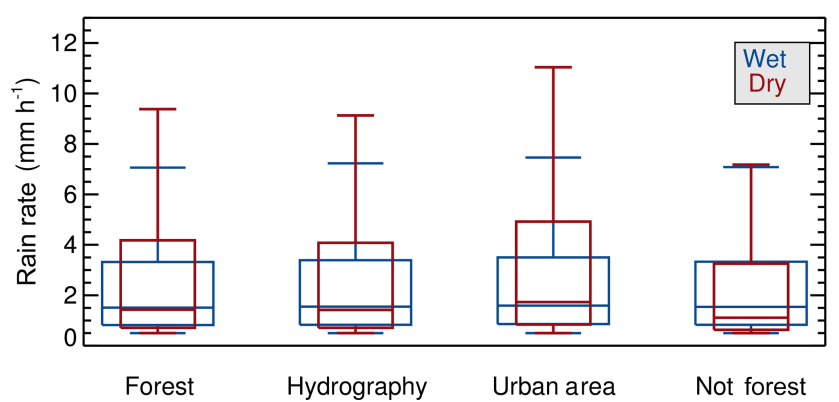

Figure 9. Rainfall rate (RR; from S-band radar) box plots for the wet and dry seasons given different surface cover classes. Each box represents the 25 to $75 \%$ populations, and the line inside the box represents the median value.

For the statistical approach, the RR was calculated from the SIPAM S-band radar data for the dry and wet seasons, as described in Sect. 2. Surface cover was obtained from the digital Terra Class classification data (Almeida et al., 2016). This database contains 15 vegetation classes, such as forest, hydrology, urban areas, and several deforestation classes, including clean and dirty pasture, deforested areas, and exposed soil. These classes were regrouped in four categories for this study: forest (covering $76.9 \%$ of the studied region), hydrography $(16.3 \%)$, non-forest $(6.2 \%)$, and urban area $(0.5 \%)$. These two datasets were combined to evaluate the different RRs for each surface cover type. Terra Class has a $300 \mathrm{~m}$ resolution and was interpolated to the radar grid using the most frequent surface type class. Figure 8 presents the spatial distribution of the vegetation classes (Fig. 8a) over the $150 \mathrm{~km}$ radius of the $\mathrm{S}$-band radar and the topography of the region (Fig. 8b).
Figure 9 shows the RR box plots for each surface type in the wet and dry seasons. This analysis does not consider cloud life cycle or the different thermodynamic or dynamic conditions that may have been present and only considers those statistics present among the different surface types. The different behaviours are a consequence of different physical processes, which will be discussed in this section.

For the wet season, the RR varies little among the different surface cover classes. However, for the dry season, a greater amount of rainfall occurred over the urban areas and smaller amounts occurred over non-forested regions. In general, the dry season RR was greater than that in the wet season. The median and tail of the distribution were larger over urban areas and smaller over deforested areas. The difference between the median values of non-forested and urban RRs in the dry season was approximately $25 \%$. Although the number of radar pixels in each class varied and the urban area represents only $0.5 \%$ of the area, the box plot patterns are different. The smaller differences during the wet season can be expected because rainfall during this season has a strong stratiform cloud component typical of a monsoon rainfall regime, as described above. In this type of regime, large-scale dynamic forcing is very strong, and surface type has little impact. However, during the dry season, rainfall events largely depend on local forcing and surface latent heat flux. Manaus, as an urban centre, is characterized by a strong heat island effect (Souza and Alvalá, 2014) that creates a convergence fed by moisture from the surrounding forest. The non-forested area has less available latent heating than the forest, which may contribute to lower RRs. These results are associated with RR and not total rainfall data. Total rainfall is larger over the forest and hydrology areas (not shown). 

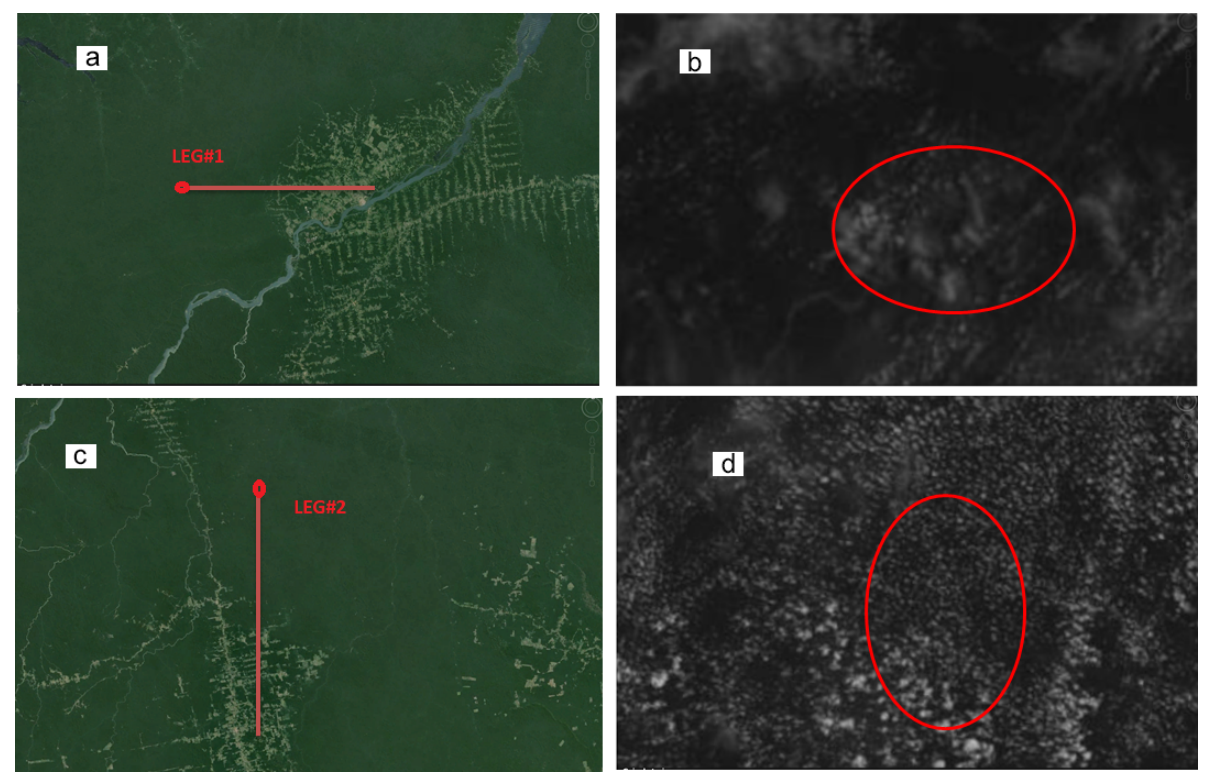

Figure 10. AC17 flight paths over forested and deforested regions. Flight legs 1 and 2 are shown in red in (a) and (c), respectively (sourced from Google Earth). The dot on flight leg 1 corresponds to $56^{\circ} 57^{\prime} \mathrm{W}, 4^{\circ} 13^{\prime} \mathrm{S}$ and that on flight leg 2 corresponds to $55^{\circ} 17^{\prime} \mathrm{W}, 5^{\circ} 53^{\prime} \mathrm{S}$. Visible GOES-13 images for flight legs 1 and 2 at the time of each flight are shown in (b) and (d), respectively.

Fisch et al. (2004) have discussed the differences in the boundary layer between forest and pasture. They show, for the Amazonas dry season, that the height of the fully developed convective boundary layer over forest is approximately $1100 \mathrm{~m}$, and it is approximately $50 \%$ higher over pasture. During the wet season, the forest and pasture have nearly the same boundary layer height (approximately $1000 \mathrm{~m}$ ). Does the different thermodynamic behaviour during the dry season result in different cloud microphysical properties and consequently different radiative forcing? This is a very important question because climate change simulations in Amazonas need to correctly reproduce the cloud processes over each of these surface covers. The results presented above consider RR and the impacts of the surface on clouds. Several physical processes play an important role in the generation of the different RRs between different surface types, such as the boundary layers described above. The effect of surface type on cloud droplet distribution under shallow convection conditions is not well understood. One of the ACRIDICONCHUVA HALO missions was especially designed to investigate this relationship. Cloud processes for different surface covers may be evaluated from a statistical point of view as a function of the surface cover using a combination of data from several different flights. However, airplane flights are limited to a few hours and measure clouds for different meteorological conditions, heights, thermodynamic conditions, and aerosol loadings that, as already stated in the set of papers published using the GoAmazon data, have a strong impact on cloud microphysical properties. Therefore, a specific flight mission was designed to evaluate this matter. The AC17 flight, which was completed on 27 Septem- ber 2014, looked at the contrast between clouds above forest and pasture surfaces. The objectives were to observe and compare macrophysical and microphysical cloud properties over both forest and pasture areas under comparable environmental conditions. As the flight legs occurred at the same fixed level, the thermodynamics and aerosol concentrations were nearly the same due to the short flight time and path $(40 \mathrm{~km})$ in each region. The two flight leg paths are shown in Fig. 10. Cloud profiling was carried out over both $40 \mathrm{~km}$ legs (red lines in Fig. 10), which included forested, transition, and pasture surface covers. The flight plan for the cloud profiling legs was designed for a fixed altitude level for each leg in order to profile clouds along the trajectories. The flight level was selected as a function of the cloud development at the local time for each flight leg. Leg 1 occurred at 15:00 UTC (11:00 LST) and leg 2 at 17:00 UTC (13:00 LST). The heights of the flights employed in this study were 1500 , 1900 , and $2500 \mathrm{~m}$. In leg 2, the cloud base was higher and the clouds were measured at 1900 and $2500 \mathrm{~m}$. In Fig. 10, the GOES visible image shows the increase in cloud cover from the first flight to the second, as well as the typical shallow cumulus clouds measured. During the morning leg 1 flight, the cloud base was nearly the same over both the forested and non-forested areas; however, during the afternoon flight, the cloud base over the non-forested area appeared to be slightly higher than that over the forested area. Therefore, some differences among clouds can also be related to measurements taken at the same height but in a different cloud layer.

Only $350 \mathrm{~s}$ of measurements from each region and at each flight level were used in this analysis. Data from the beginning of the flight over the forest, the boundary between the 

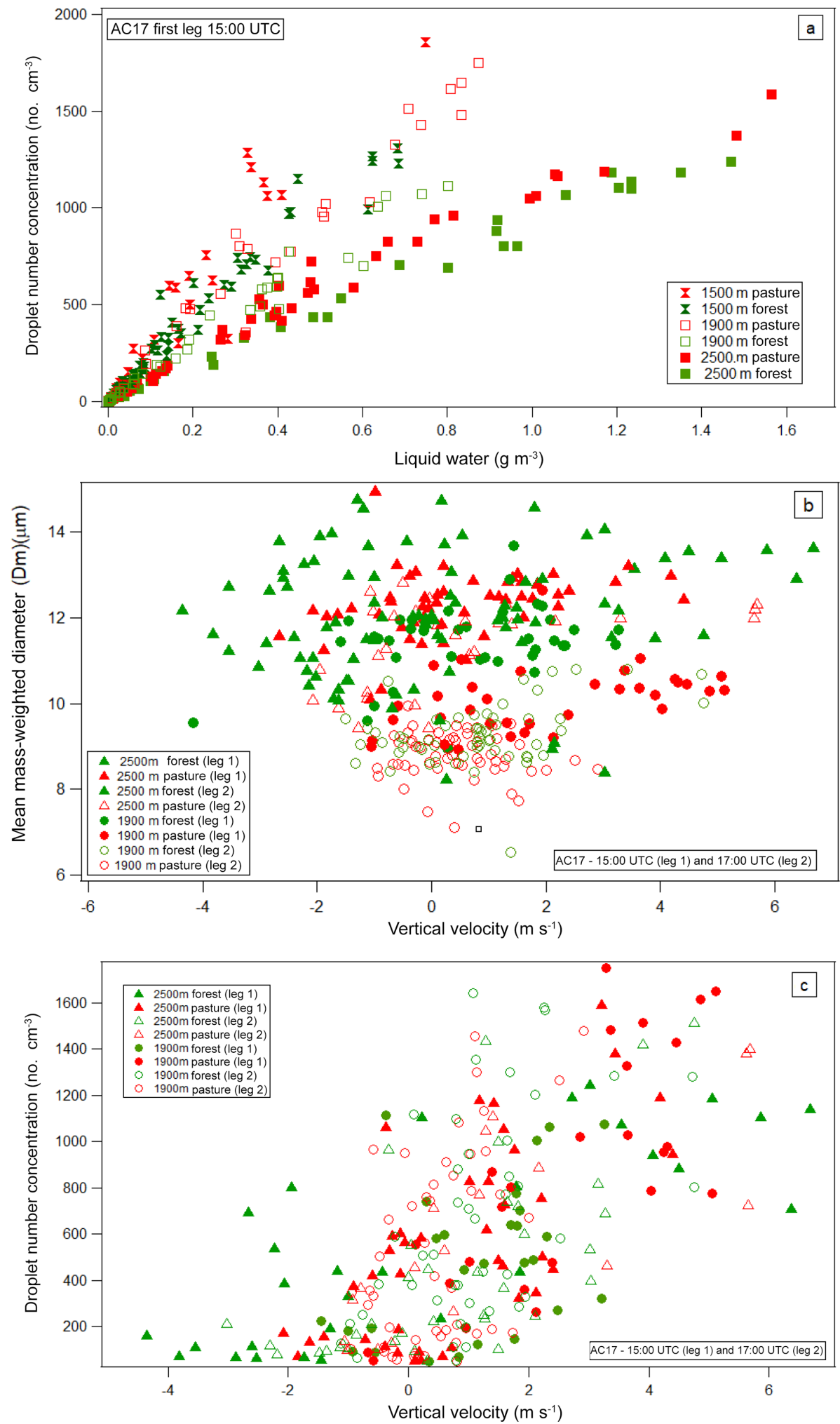

Figure 11. (a) Cloud droplet concentration as a function of liquid water content; (b) mass-weighted mean cloud diameter as a function of vertical velocity; and (c) cloud droplet concentration as a function of vertical velocity for forest and pasture at different heights. 

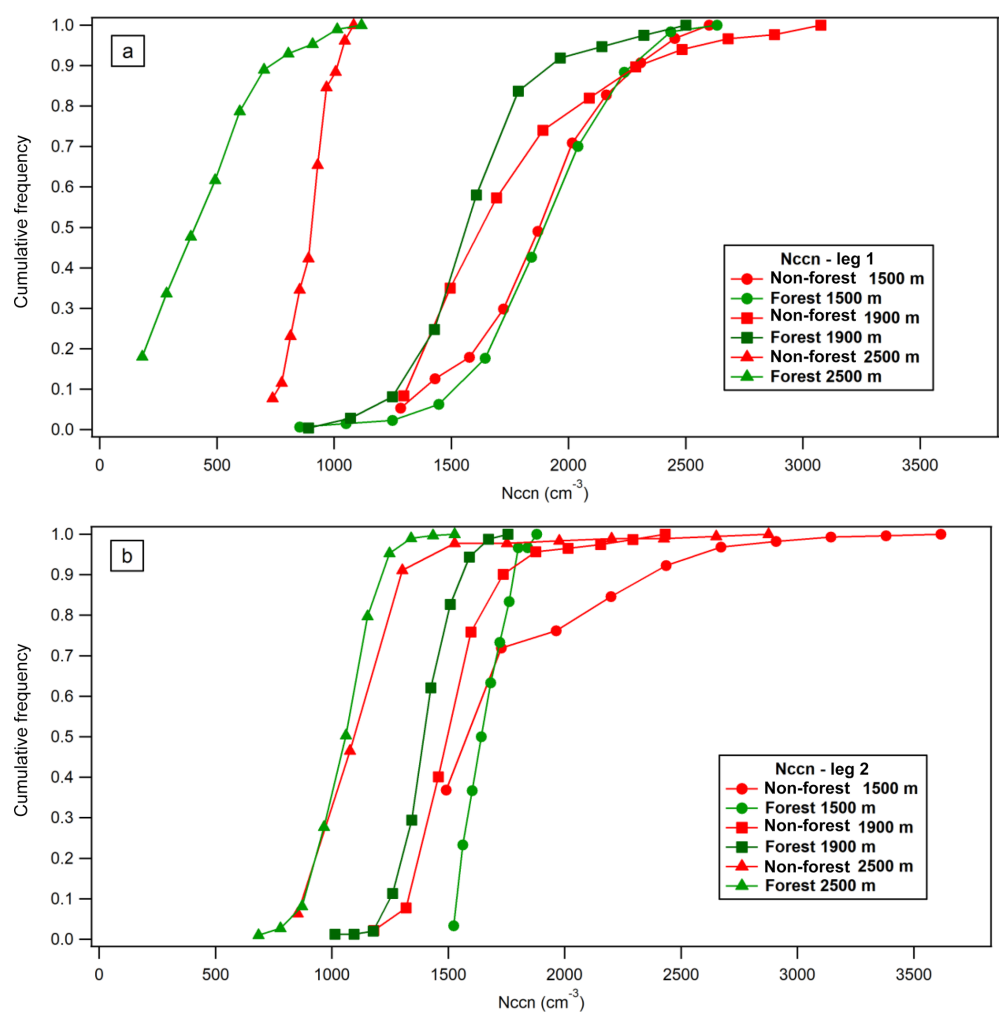

Figure 12. $\mathrm{CCN}$ concentration $\left(N_{\mathrm{CCN}}\right)$ cumulative histogram for (a) leg 1 and (b) leg 2 of AC17 flight paths over forested and non-forested regions at different flight heights.

forested and deforested region, and the final flight path over the deforested region were discarded so that only data from the centres of the forested and deforested regions were evaluated. Figure 11a shows a scatter plot of the cloud droplet concentration and liquid water content for flight leg 1 over the forest and pasture at approximately 1500, 1900, and $2500 \mathrm{~m}$. These data show a nearly linear relationship, with a correlation coefficient ranging from 0.94 to 0.99 for the relationship between cloud droplet concentration and liquid water content at varying heights. For a fixed cloud droplet concentration, clouds over the forested area have more liquid water than clouds over pasture at the same height. This means cloud droplets that develop over rain forests are larger than those that evolve over pastures. Therefore, the cloud droplet size distribution is different between the two regions, with forested areas producing larger cloud droplets.

Figure 12 shows the cumulative histogram of the CCN concentrations $\left(N_{\mathrm{CCN}}\right)$ for the two legs over the forested and non-forested regions at approximately 1500, 1900, and $2500 \mathrm{~m}$. The decrease in $N_{\mathrm{CCN}}$ with altitude for boundary layer aerosols agrees with the other flights carried out during the ACRIDICON-CHUVA campaign, as shown in Andreae et al. (2017). The magnitude of the $N_{\mathrm{CCN}}$ is typical for polluted regions in Brazil and falls between strong biomass burning events and forested regions far away from biomass burning events. For leg $1, N_{\mathrm{CCN}}$ distribution is nearly identi- cal at the 1500 and $1900 \mathrm{~m}$ flight heights for both the forested and non-forest regions; however, at $2500 \mathrm{~m}$ the distributions are quite different, with the non-forested region exhibiting a greater $N_{\mathrm{CCN}}$. For leg 2, the difference between the two surface types is larger, and the non-forested regions exhibited higher $N_{\mathrm{CCN}}$ than the forested region at all altitudes. In the first leg, the difference between forested and deforested regions increased with altitude, and the deforested regions exhibited greater $N_{\mathrm{CCN}}$. Two factors should be considered: leg 1 occurred at approximately 11:00 LST; therefore, the convective boundary layer was not fully developed, and at $2500 \mathrm{~m}$ the measurements likely represent the residual boundary layer from the previous day. Leg 2 occurred later, at approximately 13:00 LST, when the boundary layer was deeper and well mixed. Another important factor is the regional wind direction from the east; for leg 1 , the air over the forest was the air advected from the deforested region, and for leg 2, a north-south transect flight, the air was advected from the homogenous forest along the easterly side.

The cloud microphysics differences between the forested and deforested clouds are probably related to these differences in the $N_{\mathrm{CCN}}$ distributions. Some clouds over pastures have the same liquid water quantities as clouds over forests, although the pasture clouds contained higher cloud droplet concentrations. This could result from several processes, such as larger vertical motion induced by the higher sensible 
heating, the large aerosol concentration over pasture, and/or the high water availability over the forest.

Figure $11 \mathrm{~b}$ and c show the $D_{\mathrm{m}}$ and cloud droplet concentrations as a function of vertical motion. These figures illustrate that the larger cloud droplet diameter samples over the forest and the larger cloud droplet concentrations increase with vertical velocity (updraft and downdraft), but there is not a clear relationship between vertical velocity and $D_{\mathrm{m}}$. Vertical velocity increases supersaturation but does not appear to modulate droplet size. Cecchini et al. (2017a) also found that different flights demonstrated a small correlation between vertical motion and droplet size. Nevertheless, cloud droplet concentrations are more linearly related to vertical motion (the correlation coefficient is approximately 0.6 ). The stronger the updrafts are, the higher the droplet concentration is. This relationship does not appear to show differences between forested and pasture areas.

\subsubsection{Rainfall sensitivity to topography}

The topography database employed in this study included digital elevation data from the NASA Shuttle Radar Topographic Mission and has a resolution of $90 \mathrm{~m}$ at the Equator (Jarvis et al., 2008). Figure 8 shows the topographic spatial distribution within the $150 \mathrm{~km}$ radius of the radar's coverage. As the sample size decreased logarithmically relative to elevation increases, the classes were binned in log intervals as follows: from 0 to $15 \mathrm{~m}$, from 15 to $40 \mathrm{~m}$, from 40 to $83 \mathrm{~m}$, and from 83 to $157 \mathrm{~m}$. Using the S-band radar data, a statistical box plot was constructed for each topography class (Fig. 13). For the wet season, the statistics are nearly the same for all topography classes. The highest topography class shows nearly the same median but a slightly smaller tail distribution. However, for the dry season, considerable differences are found among the topography classes. The higher the land surface, the longer the RR distribution tail. During the dry season, convective inhibition is higher, as shown in Fig. 2, and cloud formation requires some kind of forcing to overcome this inhibition and take advantage of the higher CAPE available during this season. Topography is one forcing mechanism that allows this to occur, even if the differences are only a few hundred metres.

\section{Summary and conclusions}

The Amazonas climate is comprised of distinctive and complex interactions between a multitude of different physical processes that result in one of the most important rainfall production systems on Earth. Inter-annual variability is high, and in recent years, the driest and wettest years on record have been observed. El Niño, La Niña, and Atlantic Ocean temperatures are some of the inter-annual features affecting total rainfall. In addition, many synoptic conditions affect large-scale rainfall mechanisms. These are the ingredi-

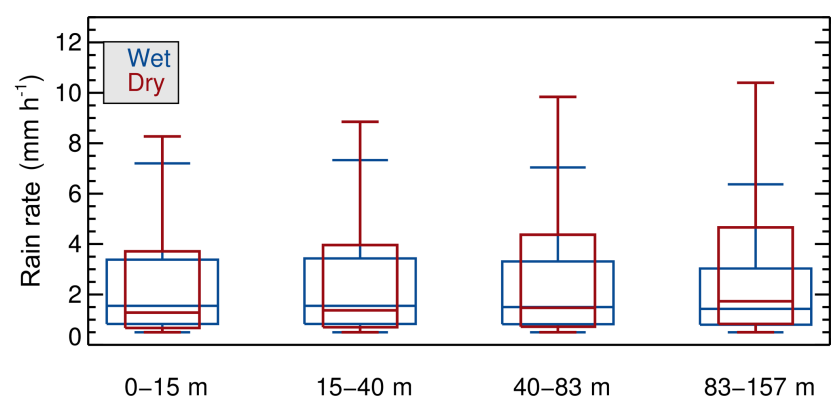

Figure 13. Wet and dry season rainfall rate (RR) box plots for different topography classes. Each box represents the 25 to $75 \%$ populations, and the line inside the box represents the median value. The line represents the remaining population.

ents necessary to generate large amounts of rainfall in Amazonas, and they are normally organized in mesoscale convective systems. Cloud and precipitation systems differ during the wet and dry seasons. Total rainfall in the wet season is 4.2 times larger than that in the dry season, but RRs observed during the dry season are approximately $22 \%$ higher than those that occur in the wet season. The wet season has a smaller CAPE, CINE, vertical wind shear, and cloud base height and a greater amount of integrated water vapour than the dry season. The wet season typically has monsoon-type rainfall, while convection occurs at a smaller scale during the dry season. The typical cloud cluster in Amazonas (wet and dry season) has an effective radius of approximately $75 \mathrm{~km}$ and a $1.5 \mathrm{~h}$ life cycle. The rain cells inside these cloud clusters have an average radius of approximately $7.5 \mathrm{~km}$ and a $0.6 \mathrm{~h}$ life cycle. Seasonality also modulates the size distribution of these features. The wet season has more small and large cloud clusters and rain cells, which are typical of isolated cumuliform convection and monsoon rainfall cloud organization. The dry season has proportionally more cloud clusters and rain cells of approximately 40 and $10 \mathrm{~km}$ radii, respectively, favouring a cloud organization that is reduced in size but larger than that of isolated convection. The differences between the two seasons are also observed in the microphysics of the clouds. Rainfall drops are larger in convective clouds during the dry season than during the wet season, likely due to enhanced ice processes. For stratiform clouds, larger drops are also observed but are not statistically significantly different.

The cloud hydrometeor vertical profile signature was evaluated for the first time in Amazonas in this study. Xband dual-polarization radar data were used to provide dualpolarization CFAD variables for the dry and wet seasons. As expected, there are differences between the dual-polarization statistical distributions between the seasons. The wet season cloud type has a typical bright band at approximately $4 \mathrm{~km}$ of altitude. The dry season has a stronger reflectivity below and above the melting layer, which is characteristic of the liquid water and ice profiles of stronger convective clouds. 
The ZDR profile of the dry season indicates more vertically oriented ice, while the KDP profile revealed larger positive values in the mixed phase, consistent with more frequent and stronger updrafts. During the dry season, the correlation coefficient indicated more heterogeneous clouds above the melting layer, with two distinct layers above and below $8 \mathrm{~km}$ of height. This indicates a clear characterization of the mixed-phase and glaciation layers.

The evaluation of the effect of aerosol concentrations on raindrop size distribution shows an interesting feature. Due to the small statistical sample of rainfall events during the dry season for different ranges of aerosol loading, it was only possible to evaluate the aerosol effect during the wet season. Clean cases show larger raindrops for lower RRs, and polluted cases show larger raindrops for higher RRs. For RR less than $8 \mathrm{~mm} \mathrm{~h}^{-1}$, typical warm rain, and less organized convective rainfall events, the clean cases have a more straightforward interpretation based on the small number of $\mathrm{CCN}$ and consequently larger droplets. However, when convection becomes deeper with increased RRs, the polluted cases seem to invigorate convection, as suggested by Rosenfeld (2008).

General statistics for how surface type impacts RR were significant only for the dry season. The wet season did not exhibit different RRs for different surface types. For the dry season, urban regions had the highest RR, and deforested regions had the lowest. This is probably related to the Manaus heat island effect, with moisture provided by the surrounding forested area and smaller latent heating fluxes in large deforested areas. Nearly identical cloud properties were measured by the HALO airplane over the forested and deforested areas. The specific flight design, which allowed for an evaluation of the microphysical differences in shallow convective cloud formation, provided unprecedented data to study these differences under nearly the same synoptic and environmental conditions. Nearly simultaneous flight legs at the same height, along a short path of only $40 \mathrm{~km}$, allowed us to compare cloud processes over different surfaces types. As a result, clouds over forested areas were observed to have larger cloud droplets, and in general the vertical velocity was well correlated with cloud droplet concentrations. However, these data did not correlate with mass-weighted mean cloud droplet diameter.

Finally, the impact of topography on the RR was evaluated. There was no difference in the RR during the wet season for different topography classes. For the dry season, there was a clear increase in the RR as elevation increased. This was probably related to the topographical forcing required to overcome the large CINE and take advantage of the large CAPE available during this season.

The GoAmazon dataset brings new insights into the process of cloud and rainfall formation in the Amazon and to those complexities requiring further research. The entire dataset is likely to have a very high potential impact on the modelling of aerosol, cloud, and landscape features in tropical scenarios. Nevertheless, there are several areas that still necessitate further research to complete the picture of cloud processes in Amazonas. For instance, a detailed microphysical description of clouds as a function of the two patterns of convection, cumuliform, and deep convection is still wanting (see Wang et al., 2018). Changes in the microphysical properties and mixed phase are some of the unknown behaviours of cloud processes. How these processes change as function of the season, cloud life cycle, aerosol loading, and topography are some examples of areas in need of further research to improve the cloud modelling over continental tropical regions. Another potential area for future study includes the implications and solutions for GCMs, which may not resolve subtle variations in topography but are very important in triggering convection during the dry season.

Data availability. All ARM datasets used for this study may be downloaded at http://www.arm.gov as well as the data from the CHUVA project dataset URLs: http://chuvaproject.cptec.inpe.br/ portal. The full data set from the ACRIDICON-CHUVA campaign is archived and publicly accessible from the HALO database maintained by the German Aerospace Center (DLR) at https://halo-db. pa.op.dlr.de/mission/5.

Competing interests. The authors declare that they have no conflict of interest.

Special issue statement. This article is part of the special issues "Observations and Modeling of the Green Ocean Amazon (GoAmazon2014/5) (ACP/AMT/GI/GMD inter-journal SI)" and "The ACRIDICON-CHUVA campaign to study deep convective clouds and precipitation over Amazonia using the new German HALO research aircraft (ACP/AMT inter-journal SI)". It is not associated with a conference.

Acknowledgements. We thank all participants in GoAmazon2014/5 and ACRIDICON-CHUVA for their cooperation and for making this study possible. We acknowledge FAPESP (São Paulo Research Foundation) projects 2009/15235-8, 2014/08615-7, and 2015/14497-0. This work was conducted under scientific licences 001030/2012-4, 001262/2012-2, and 00254/2013-9 of the Brazilian National Council for Scientific and Technological Development $(\mathrm{CNPq})$. Institutional support was provided by the Central Office of the Large-Scale Biosphere Atmosphere Experiment in Amazonia (LBA), the National Institute of Amazonian Research (INPA), the National Institute for Space Research (INPE), Amazonas State University (UEA), and the Brazil Space Agency (AEB). We acknowledge the support of the Max Planck Society, the German Aerospace Centre (DLR), and the German Science Foundation (Deutsche Forschungsgemeinschaft, DFG) within the DFG Priority Programme SPP 1294 for the ACRIDICON-CHUVA campaign. We also acknowledge the Atmospheric Radiation Measurement (ARM) Climate Research Facility, a user facility of the US DOE Office of Science sponsored by the Office of Biological and Environmental Research, and 
support from the ASR programme. Jiwen Fan was supported by the Climate Model Development and Validation programme funded by the Office of Biological and Environmental Research in the US Department of Energy Office of Science. R. Albrecht was supported by $\mathrm{CNPq} 459546 / 2014-7$. We acknowledge Yizhou Zhuang and anonymous reviewers for their comments and suggestions.

Edited by: Timothy Garrett

Reviewed by: Yizhou Zhuang and one anonymous referee

\section{References}

Adams, D. K., Fernandes, R. M., Holub, K. L., Gutman, S. I., Barbosa, H. M., Machado, L. A., Calheiros, A. J., Bennett, R. A., Kursinski, E. R., Sapucci, L. F., DeMets, C., Chagas, G. F., Arellano, A., Filizola, N., Amorim Rocha, A. A., Silva, R. A., Assunção, L. M., Cirino, G. G., Pauliquevis, T., Portela, B. T., Sá, A., de Sousa, J. M., and Tanaka, L. M.: The Amazon Dense GNSS Meteorological Network: A New Approach for Examining Water Vapor and Deep Convection Interactions in the Tropics, B. Am. Meteorol. Soc., 96, 2151-2165, https://doi.org/10.1175/BAMS-D-13-00171.1, 2015.

Albrecht, R. I., Morales, C. A., and Silva Dias, M. A. F.: Electrification of precipitating systems over the Amazon: Physical processes of thunderstorm development, J. Geophys. Res., 116, D08209, https://doi.org/10.1029/2010JD014756, 2011.

Almeida, C. A., Coutinho, A. C., Esquerdo, J. C. D. M., Adami, M., Venturieri, A., Diniz, C. G., Dessay, N., Durieux, L., and Gomes, A. R.: High spatial resolution land use and land cover mapping of the Brazilian Legal Amazon in 2008 using Landsat-5/TM and MODIS data, Acta Amazonica, 46, 291-302, 2016.

Andreae, M. O., Artaxo, P., Fischer, H., Freitas, S. R., Lelieveld, J., Dias, M. A. F. S., Freitas, S., and Longo, K. M., and Strom, J.: Transport of biomass burning smoke to the upper troposphere by deep convection in the equatorial region, J. Geophys. Res., 28, 951-954, 2001.

Andreae, M. O., Rosenfeld, D., Artaxo, P., Costa, A. A., Frank, G. P., Longo, K. M., and Silva Dias, M. A.: Smoking rain clouds over the Amazon, Science, 303, 1337-1342, 2004.

Andreae, M. O., Afchine, A., Albrecht, R., Holanda, B. A., Artaxo, P., Barbosa, H. M. J., Bormann, S., Cecchini, M. A., Costa, A., Dollner, M., Fütterer, D., Järvinen, E., Jurkat, T., Klimach, T., Konemann, T., Knote, C., Krämer, M., Krisna, T., Machado, L. A. T., Mertes, S., Minikin, A., Pöhlker, C., Pöhlker, M. L., Pöschl, U., Rosenfeld, D., Sauer, D., Schlager, H., Schnaiter, M., Schneider, J., Schulz, C., Spanu, A., Sperling, V. B., Voigt, C., Walser, A., Wang, J., Weinzierl, B., Wendisch, M., and Ziereis, H.: Aerosol characteristics and particle production in the upper troposphere over the Amazon Basin, Atmos. Chem. Phys. Discuss., https://doi.org/10.5194/acp-2017-694, in review, 2017.

Artaxo, P., Martins, J. V., Yamasoe, M. A., Procópio, A. S., Pauliquevis, T. M., Andreae, M. O., Guyon, P., Gatti, L. V., and Leal, A. M. C.: Physical and chemical properties of aerosols in the wet and dry season in Rondonia, Amazonia, J. Geophys. Res., 107, 8081-8095, 2002.

Betts, A. K., Gatti, L. V., Cordova, A. M., Silva Dias, M. A. F., and Fuentes, J. D.: Transport of ozone to the surface by convective downdrafts at night, J. Geophys. Res., 107, 1-13, 2002.
Braga, R. C., Rosenfeld, D., Weigel, R., Jurkat, T., Andreae, M. O., Wendisch, M., Pöhlker, M. L., Klimach, T., Pöschl, U., Pöhlker, C., Voigt, C., Mahnke, C., Borrmann, S., Albrecht, R. I., Molleker, S., Vila, D. A., Machado, L. A. T., and Artaxo, P.: Comparing parameterized versus measured microphysical properties of tropical convective cloud bases during the ACRIDICON-CHUVA campaign, Atmos. Chem. Phys., 17, 7365-7386, https://doi.org/10.5194/acp-17-7365-2017, 2017.

Bringi, V. N., Huang, G.-J., Chandrasekar, V., and Gorgucci, E.: A methodology for estimating the parameters of a gamma raindrop size distribution model from polarimetric radar data: Application to a squall-line event from the TRMM/Brazil campaign, J. Atmos. Ocean. Tech., 19, 633-645, 2002.

Burleyson, C., Feng, Z., Hagos, S., Fast, J., Machado, L., and Martin, S.: Spatial Variability of the Background Diurnal Cycle of Deep Convection around the GoAmazon2014/5 Field Campaign Sites, J. Appl. Meteorol. Clim., 55, 1579-1598, https://doi.org/10.1175/JAMC-D-15-0229.1, 2016.

Camponogara, G., Silva Dias, M. A. F., and Carrió, G. G.: Relationship between Amazon biomass burning aerosols and rainfall over the La Plata Basin, Atmos. Chem. Phys., 14, 4397-4407, https://doi.org/10.5194/acp-14-4397-2014, 2014.

Cavalcanti, I. F. A., Ferreira, N. J., and Silva, M. G. A. J. (Eds.): Weather and Climate in Brazil (Tempo e Clima no Brasil - in Portuguese), Oficina de Texto, São Paulo, Brazil, 463 pp., 2009.

Cecchini, M. A., Machado, L. A. T., Comstock, J. M., Mei, F., Wang, J., Fan, J., Tomlinson, J. M., Schmid, B., Albrecht, R., Martin, S. T., and Artaxo, P.: Impacts of the Manaus pollution plume on the microphysical properties of Amazonian warmphase clouds in the wet season, Atmos. Chem. Phys., 16, 70297041, https://doi.org/10.5194/acp-16-7029-2016, 2016.

Cecchini, M. A., Machado, L. A. T., Andreae, M. O., Martin, S. T., Albrecht, R. I., Artaxo, P., Barbosa, H. M. J., Borrmann, S., Fütterer, D., Jurkat, T., Mahnke, C., Minikin, A., Molleker, S., Pöhlker, M. L., Pöschl, U., Rosenfeld, D., Voigt, C., Weinzierl, B., and Wendisch, M.: Sensitivities of Amazonian clouds to aerosols and updraft speed, Atmos. Chem. Phys., 17, 1003710050, https://doi.org/10.5194/acp-17-10037-2017, 2017a.

Cecchini, M. A., Machado, L. A. T., Wendisch, M., Costa, A., Krämer, M., Andreae, M. O., Afchine, A., Albrecht, R. I., Artaxo, P., Borrmann, S., Fütterer, D., Klimach, T., Mahnke, C., Martin, S. T., Minikin, A., Molleker, S., Pardo, L. H., Pöhlker, C., Pöhlker, M. L., Pöschl, U., Rosenfeld, D., and Weinzierl, B.: Illustration of microphysical processes in Amazonian deep convective clouds in the gamma phase space: introduction and potential applications, Atmos. Chem. Phys., 17, 14727-14746, https://doi.org/10.5194/acp-17-14727-2017, 2017b.

Cifelli, R., Petersen, W. A., Carey, L. D., Rutledge, S. A., and Silva Dias, M. A. F.: Radar observations of kinematic, microphysical, and precipitation characteristics of two MCSs in TRMM-LBA, J. Geophys. Res., 107, 8077, https://doi.org/10.1029/2000JD000264, 2002.

Cohen, J. C. P., Silva Dias, M. A. F., and Nobre, C. A.: Environmental conditions associated with Amazonian squall lines: A case study, Mon. Weather Rev., 123, 3163-3174, 1995.

Diedhiou, A., Machado, L. A. T., and Laurent, H.: Mean kinematic characteristics of synoptic easterly disturbances over the Atlantic, Adv. Atmos. Sci., 27, 483-499, 2010. 
Dos Santos, M. J., Silva Dias, M. A. F., and Freitas, E. D.: Influence of local circulations on wind, moisture, and precipitation close to Manaus City, Amazon Region, Brazil, J. Geophys. Res.-Atmos., 119, 233-249, https://doi.org/10.1002/2014JD021969, 2014.

Durieux, L., Machado, L. A. T., and Laurent, H.: The impact of deforestation on cloud cover over the Amazon arc of deforestation, Remote Sens. Environ., 86, 132-140, 2003.

Fisch, G., Tota, J., Machado, L. A. T., Silva Dias, M. A. F., Lyra, R. F., Nobre, C. A., Dolman, A. J., and Gash, J. H. C.: The convective boundary layer over pasture and forest in Amazonia, Theor. Appl. Climatol. 78, 47-59, https://doi.org/10.1007/s00704-0040043-x, 2004.

Fitzjarrald, D. R., Sakai, R. K., Moraes, O. L. L., Oliveira, R. C., Acevedo, O. C., Czikowsky, M. J., and Beldini, T.: Spatial and temporal rainfall variability near the Amazon-Tapajós confluence, J. Geophys. Res., 113, G00B11, https://doi.org/10.1029/2007JG000596, 2008.

Freitas, S. R., Longo, K. M., Silva Dias, M., Silva Dias, P., Chatfield, R., Prins, E., Artaxo, P., Grell, G., and Recuero, F.: Monitoring the transport of biomass burning emissions in South America, Environ. Fluid Mech., 5, 135-167, https://doi.org/10.1007/s10652-005-0243-7, 2005.

Freitas, S. R., Panetta, J., Longo, K. M., Rodrigues, L. F., Moreira, D. S., Rosário, N. E., Silva Dias, P. L., Silva Dias, M. A. F., Souza, E. P., Freitas, E. D., Longo, M., Frassoni, A., Fazenda, A. L., Santos e Silva, C. M., Pavani, C. A. B., Eiras, D., França, D. A., Massaru, D., Silva, F. B., Santos, F. C., Pereira, G., Camponogara, G., Ferrada, G. A., Campos Velho, H. F., Menezes, I., Freire, J. L., Alonso, M. F., Gácita, M. S., Zarzur, M., Fonseca, R. M., Lima, R. S., Siqueira, R. A., Braz, R., Tomita, S., Oliveira, V., and Martins, L. D.: The Brazilian developments on the Regional Atmospheric Modeling System (BRAMS 5.2): an integrated environmental model tuned for tropical areas, Geosci. Model Dev., 10, 189-222, https://doi.org/10.5194/gmd-10-189-2017, 2017.

Fu, R., Yin, L., Li, W., Arias, P. A., Dickinson, R. E., Huang, L., Chakraborty, S., Fernandes, K., Liebmann, B., Fisher, R., and Myneni, R. B.: Increased dry-season length over southern Amazonia in recent decades and its implication for future climate projection, P. Natl. Acad. Sci. USA, 110, 18110-18115, https://doi.org/10.1073/pnas.1302584110, 2013.

Garstang, M., Massie, H. L., Halverson Jr., J., Greco, S., and Scala, J.: Amazon coastal squall lines. Part 1: Structure and kinematics, Mon. Weather Rev., 122, 608-622, 1994.

Gash, J. H. C., Nobre, A., Roberts, J. M., and Victoria, R. L. (Eds.): An overview of ABRACOS, in: Amazon Deforestation and Climate, John Wiley, New York, 1996.

Gerken, T., Wei, D., Chase, R. J., Fuentes, J. D., Schumacher, C., Machado, L. A. T., Andreoli, R. V., Chamecki, M., Souza, R. A. F., Freire, L. S., Jardine, A. B., Manzi, A. O., Santos, R. M. N., Randow, C. V., Costa, P. S., Stoy, P. C., Tóta, J., and Trowbridge, A. M.: Downward transport of ozone rich air and implications for atmospheric chemistry in the Amazon rainforest, Atmos. Environ. A, 124, 64-76, https://doi.org/10.1016/j.atmosenv.2015.11.014, 2015.

Giangrande, S. E., Toto, T., Jensen, M. P., Bartholomew, M. J., Feng, Z., Protat, A. and Machado, L. A. T.: Convective cloud vertical velocity and mass-flux characteristics from radar wind profiler observations during GoAmazon2014/5, J. Geophys. Res.-
Atmos., 121, 891-913, https://doi.org/10.1002/2016JD025303, 2016.

Giangrande, S. E., Feng, Z., Jensen, M. P., Comstock, J. M., Johnson, K. L., Toto, T., Wang, M., Burleyson, C., Bharadwaj, N., Mei, F., Machado, L. A. T., Manzi, A. O., Xie, S., Tang, S., Silva Dias, M. A. F., de Souza, R. A. F., Schumacher, C., and Martin, S. T.: Cloud characteristics, thermodynamic controls and radiative impacts during the Observations and Modeling of the Green Ocean Amazon (GoAmazon2014/5) experiment, Atmos. Chem. Phys., 17, 14519-14541, https://doi.org/10.5194/acp-1714519-2017, 2017.

Gonçalves, W. A., Machado, L. A. T., and Kirstetter, P.-E.: Influence of biomass aerosol on precipitation over the Central Amazon: an observational study, Atmos. Chem. Phys., 15, 6789-6800, https://doi.org/10.5194/acp-15-6789-2015, 2015.

Gorgucci, E., Scarchilli, G., and Chandrasekar, V.: A procedure to calibrate multiparameter weather radar using properties of the rain medium, IEEE T. Geosci. Remote, 37, 269-276, 1999.

Greco, S., Swap, R., Garstang, M., Ulanski, S., Shipham, M., Harriss, R. C., Talbot, R., Andreae, M. O., and Artaxo, P.: Rainfall and surface kinematic conditions over central Amazonia during ABLE 2B, J. Geophys. Res., 95, 1-14, 1990.

Greco, S., Scala, J., Halverson, J., Massie Jr., H. L., Tao-K, W., and Garstang, M.: Amazon coastal squall lines. Part II: Heat and moisture transports, Mon. Weather Rev., 122, 623-635, 1994.

Harriss, R. C., Wofsy, S. C., Garstang, M., Browell, E. V., Molion, L. C. B., McNeal, R. J., Hoell, J. M., Bendura, R. J., Beck, S. M., Navarro, R. L., Riley, J. T., and Snell, R. L.: The Amazon Boundary Layer Experiment (ABLE-2A): Dry season 1985, J. Geophys. Res., 93, 1351-1360, 1988.

Harriss, R. C., Garstang, M., Wofsy, S. C., Beck, S. M., Bendura, R. J., Coelho, J. R. B., Drewry, J. W., Hoell, J. M., Matson Jr., P. A., McNeal, R. J., Molion, L. C. B., Navarro, R. L., Rabine, V., and Snell, R. L.: The Amazon Boundary Layer Experiment: Wet season 1987, J. Geophys. Res., 95, 721-736, 1990.

Horel, J., Hahmann, A., and Geisler, J.: An investigation of the annual cycle of the convective activity over the tropical Americas, Journal of Climate, 2, 1388-1403, 1989.

Hubbert, J. and Bringi, V. N.: An iterative filtering technique for the analysis of copolar differential phase and dual-frequency radar measurements, J. Atmos. Ocean. Tech., 12, 643-648, 1995.

Jäkel, E., Wendisch, M., Krisna, T. C., Ewald, F., Kölling, T., Jurkat, T., Voigt, C., Cecchini, M. A., Machado, L. A. T., Afchine, A., Costa, A., Krämer, M., Andreae, M. O., Pöschl, U., Rosenfeld, D., and Yuan, T.: Vertical distribution of the particle phase in tropical deep convective clouds as derived from cloud-side reflected solar radiation measurements, Atmos. Chem. Phys., 17, 9049-9066, https://doi.org/10.5194/acp-17-9049-2017, 2017.

Jarvis, A., Reuter, H. I., Nelson, A., and Guevara, E.: Hole-filled seamless SRTM data V4, International Centre for Tropical Agriculture (CIAT), available at: http://srtm.csi.cgiar.org (last access: May 2018), 2008.

Koren, I., Altaratz, O., Remer, L. A., Feingold, G., Martins, J. V., and Heiblum, R. H.: Aerosol-induced intensification of rain from the tropics to the mid-latitudes, Nat. Geosci., 5, 118-122, https://doi.org/10.1038/ngeo1364, 2012.

Kousky, V. E. and Gan, M. A.: Upper tropospheric cyclonic vortices in the tropical South Atlantic, Tellus, 33, 538-551, 1981. 
Lance, S., Brock, C. A., Rogers, D., Gordon, J. A.: Water droplet calibration of the Cloud Droplet Probe (CDP) and inflight performance in liquid, ice and mixed-phase clouds during ARCPAC, Atmos. Meas. Tech., 3, 1683-1706, https://doi.org/10.5194/amt3-1683-2010, 2010.

Laurent, H., Machado, L. A. T., Morales, C. A., and Durieux, L.: Characteristics of the Amazonian mesoscale convective systems observed from satellite and radar during the WETAMC/LBA experiment, J. Geophys. Res., 107, 8054, https://doi.org/10.1029/2001JD000337, 2002.

Lin, C. Y., Chen, W. C., Chang, P. L., and Sheng, Y. F.: Impact of the urban heat island effect on precipitation over a complex geographic environment in northern Taiwan, J. Appl. Meteorol. Clim., 50, 339-353, 2010.

Löffler-Mang, M. and Joss, J.: An optical disdrometer for measuring size and velocity of hydrometeors, J. Atmos. Ocean. Tech., 17, 130-139, 2000.

Machado, L. A. T., Desbois, M., and Duvel, J. P.: Structural Characteristics of Deep Convective Systems over Tropical Africa and the Atlantic Ocean, Mon. Weather Rev., 120, 392-406, 1992.

Machado, L. A. T., Rossow, W., Guedes, R. L., and Walker, A.: Life cycle variations of mesoescale convective systems over the Americas, Mon. Weather Rev., 126, 1630-1654, 1998.

Machado, L. A. T., Laurent, H., and Lima, A. A.: Diurnal march of the convection observed during TRMM-WETAMC/LBA, J. Geophys. Res., 107, 8064, https://doi.org/10.1029/2001JD000338, 2002.

Machado, L. A. T., Laurent, H., Dessay, N., and Miranda, I.: Seasonal and diurnal variability of convection over the Amazonia: A comparison of different vegetation types and large scale forcing, Theor. Appl. Climatol., 78, 61, https://doi.org/10.1007/s00704004-0044-9, 2004.

Machado, L. A., Silva Dias, M. A., Morales, C., Fisch, G., Vila, D., Albrecht, R., Goodman, S. J., Calheiros, A. J., Biscaro, T., Kummerow, C., Cohen, J., Fitzjarrald, D., Nascimento, E. L., Sakamoto, M. S., Cunningham, C., Chaboureau, J., Petersen, W. A., Adams, D. K., Baldini, L., Angelis, C. F., Sapucci, L. F., Salio, P., Barbosa, H. M., Landulfo, E., Souza, R. A., Blakeslee, R. J., Bailey, J., Freitas, S., Lima, W. F., and Tokay, A.: The Chuva Project: How Does Convection Vary across Brazil?, B. Am. Meteorol. Soc., 95, 1365-1380, https://doi.org/10.1175/BAMS-D-13-00084.1, 2014.

Mallaun, C., Giez, A., and Baumann, R.: Calibration of 3-D wind measurements on a single-engine research aircraft, Atmos. Meas. Tech., 8, 3177-3196, https://doi.org/10.5194/amt-8-3177-2015, 2015.

Marengo, J. A., Cornejo, A., Satymurty, P., Nobre, C., and Sea, W.: Cold surges in tropical and extratropical South America: The strong event in June 1994, Mon. Weather Rev., 125, 2759-2786, 1997.

Marengo, J. A., Borma, L. S., Rodriguez, D. A., Pinho, P., Soares, W. R., and Alves, L. M.: Recent Extremes of Drought and Flooding in Amazonia: Vulnerabilities and Human Adaptation, Am. J. Clim. Change, 02, 87-96, 2013.

Marengo, J. A., Williams, E. R., Alves, L. M., Soares, W. R., Rodrigues, D. A. (Eds.): Exteme seasonal variations in the Amazon Basin: droughts and floods, in: Interaction between biosphere, atmosphere and human land use in the Amazon basin, edited by: Nagy, L., Forsberg, B. R., and Artaxo, P., Springer-Verlag, Berlin, Heidelberg, 55-76, 2016.

Martin, S. T., Andreae, M. O., Artaxo, P., Baumgardner, D., Chen, Q., Goldstein, A. H., Guenther, A., Heald, C. L., MayolBracero, O. L., McMurry, P. H., Pauliquevis, T., Pöschl, U., Prather, K. A., Roberts, G. C., Saleska, S. R., Dias, M. A. S., Spracklen, D., Swietlicki, E., and Trebs, I.: Sources and properties of Amazonian aerosol particles, Rev. Geophys., 48, RG2002, https://doi.org/10.1029/2008RG000280, 2010.

Martin, S. T., Artaxo, P., Machado, L. A. T., Manzi, A. O., Souza, R. A. F., Schumacher, C., Wang, J., Andreae, M. O., Barbosa, H. M. J., Fan, J., Fisch, G., Goldstein, A. H., Guenther, A., Jimenez, J. L., Pöschl, U., Silva Dias, M. A., Smith, J. N., and Wendisch, M.: Introduction: Observations and Modeling of the Green Ocean Amazon (GoAmazon2014/5), Atmos. Chem. Phys., 16, 47854797, https://doi.org/10.5194/acp-16-4785-2016, 2016.

Martin, S. T., Artaxo, P., Machado, L., Manzi, A. O., Souza, R. A., Schumacher, C., Wang, J., Biscaro, T., Brito, J., Calheiros, A., Jardine, K., Medeiros, A., Portela, B., de Sá, S. S., Adachi, K., Aiken, A. C., Albrecht, R., Alexander, L., Andreae, M. O., Barbosa, H. M., Buseck, P., Chand, D., Comstock, J. M., Day, D. A., Dubey, M., Fan, J., Fast, J., Fisch, G., Fortner, E., Giangrande, S., Gilles, M., Goldstein, A. H., Guenther, A., Hubbe, J., Jensen, M., Jimenez, J. L., Keutsch, F. N., Kim, S., Kuang, C., Laskin, A., McKinney, K., Mei, F., Miller, M., Nascimento, R., Pauliquevis, T., Pekour, M., Peres, J., Petäjä, T., Pöhlker, C., Pöschl, U., Rizzo, L., Schmid, B., Shilling, J. E., Dias, M. A., Smith, J. N., Tomlinson, J. M., Tóta, J., and Wendisch, M.: The Green Ocean Amazon Experiment (GoAmazon2014/5) Observes Pollution Affecting Gases, Aerosols, Clouds, and Rainfall over the Rain Forest, B. Am. Meteorol. Soc., 98, 981-997, https://doi.org/10.1175/BAMS-D-15-00221.1, 2017.

Mattos, E. V., Machado, L. A. T., Williams, E. R., Goodman, S. J., Blakeslee, R. J., and Bailey, J.: Electrification Life Cycle of Incipient Thunderstorms, J. Geophys. Res.-Atmos., 122, 4670 4697, 2017.

Molleker, S., Borrmann, S., Schlager, H., Luo, B., Frey, W., Klingebiel, M., Weigel, R., Ebert, M., Mitev, V., Matthey, R., Woiwode, W., Oelhaf, H., Dörnbrack, A., Stratmann, G., Grooß, J.U., Gün-ther, G., Vogel, B., Müller, R., Krämer, M., Meyer, J., and Cairo, F.: Microphysical properties of syn-optic scale polar stratospheric clouds: in situ measurements of unexpectedly large $\mathrm{HNO}_{3}$ containing particles in the Arctic vortex, Atmos. Chem. Phys., 14, 10785-10801, https://doi.org/10.5194/acp-14-107852014, 2014.

Negri, A. J., Anagnostou, E. N., and Adler, R. F.: A 10$\mathrm{yr}$ climatology of Amazonian rainfall derived from passive microwave satellite observations, J. Appl Meteorol., $\quad 39, \quad 42-56, \quad$ https://doi.org/10.1175/15200450(2000)039<0042:AYCOAR>2.0.CO;2, 2000.

Petersen, W. A. and Rutledge, S. A.: Regional Variability in Tropical Convection: Observations from TRMM, J. Climate, 14, 3566-3585, 2001

Pöhlker, M. L., Pöhlker, C., Klimach, T., Hrabe de Angelis, I., Barbosa, H. M. J., Brito, J., Carbone, S., Cheng, Y., Chi, X., Ditas, F., Ditz, R., Gunthe, S. S., Kesselmeier, J., Könemann, T., Lavrič, J. V., Martin, S. T., Moran-Zuloaga, D., Rose, D., Saturno, J., Su, H., Thalman, R., Walter, D., Wang, J., Wolff, S., Artaxo, P., Andreae, M. O., and Pöschl, U.: Long-term observations of cloud 
condensation nuclei in the Amazon rain forest - Part 1: Aerosol size distribution, hygroscopicity, and new model parameterizations for CCN prediction, Atmos. Chem. Phys., 16, 1570915740, https://doi.org/10.5194/acp-16-15709-2016, 2016.

Rickenbach, T. M.: Nocturnal cloud systems and the diurnal variation of clouds and rainfall in southwestern Amazonia, Mon. Weather Rev., 132, 1201-1219, https://doi.org/10.1175/15200493(2004)132<1201:NCSATD>2.0.CO;2, 2004.

Rickenbach, T. M., Ferreira, R. N., Halverson, J., and Silva Dias, M. A. F.: Modulation of convection in the southwestern Amazon basin by extratropical stationary fronts, J. Geophys. Res., 107, 8040, https://doi.org/10.1029/2000JD000263, 2002.

Roberts, G. C., Andreae, M. O., Zhou, J., and Artaxo, P.: Cloud condensation nuclei in the Amazon Basin: "Marine" conditions over a continent?, Geophys. Res. Lett., 28, 2807-2810, 2001.

Rose, D., Gunthe, S. S., Mikhailov, E., Frank, G. P., Dusek, U., Andreae, M. O., and Pöschl, U.: Calibration and measurement uncertainties of a continuous-flow cloud condensation nuclei counter (DMT-CCNC): CCN activation of ammonium sulfate and sodium chloride aerosol particles in theory and experiment, Atmos. Chem. Phys., 8, 1153-1179, https://doi.org/10.5194/acp8-1153-2008, 2008.

Rosenfeld, D.: Flood or drought: How do aerosols affect precipitation?, Science, 321, 1309-1313, 2008.

Rosenfeld, D. and Ulbrich, C. W. (Eds.): Cloud microphysical properties, processes, and rainfall estimation opportunities, in: chap. 10 of "Radar and Atmospheric Science: A Collection of Essays in Honor of David Atlas", edited by: Wakimoto, R. M. and Srivastava, R., Meteorol. Monogr., 52, 237-258, 2003.

Saad, S. I., da Rocha, H. R., Silva Dias, M. A. F., and Rosolem, R.: Can the Deforestation Breeze Change the Rainfall in Amazonia? A Case Study for the BR-163 Highway Region, Earth Interact., $14,1-25,2010$.

Saraiva, I., Silva Dias, M. A. F., Morales, C. A. R., and Saraiva, J. M. B.: Regional variability of rainclouds in the Amazon basin seen by a network of weather radars, J. Appl. Meteorol. Clim., 55, 2657-2675, https://doi.org/10.1175/JAMC-D-150183.1, 2016.

Schneebeli, M., Sakuragi, J., Biscaro, T., Angelis, C. F., Carvalho da Costa, I., Morales, C., Baldini, L., and Machado, L. A. T.: Polarimetric X-band weather radar measurements in the tropics: radome and rain attenuation correction, Atmos. Meas. Tech., 5, 2183-2199, https://doi.org/10.5194/amt-5-2183-2012, 2012.

Shilling, J. E., Pekour, M. S., Fortner, E. C., Artaxo, P., de Sá, S., Hubbe, J. M., Longo, K. M., Machado, L. A. T., Martin, S. T., Springston, S. R., Tomlinson, J., and Wang, J.: Aircraft Observations of Aerosol in the Manaus Urban Plume and Surrounding Tropical Forest during GoAmazon 2014/15, Atmos. Chem. Phys. Discuss., https://doi.org/10.5194/acp-2018-193, in review, 2018.

Silva Dias, M. A. F. and Carvalho, L. M. V.: The South American Monsoon System, in: The Global Monsoon System Research and Forecast, chap. 3, 3rd Edn., edited by: Chang, C. P., World Scientific Publishing Co., https://doi.org/10.1142/9789813200913_0003, 2016.

Silva Dias, M. A. F., Rutledge, S., Kabat, P., Silva Dias, P. L., Nobre, C. A., Fisch, G., Dolman, A J, Zipser, E., Garstang, M., Manzi, A. O., Fuentes, J., Rocha, H. R., Marengo, J., Plana-Fattori, A., Sá, L., Alvalá, R., Andreae, M., Artaxo, P., Gielow, R., and Gatti, L.: Clouds and rain processes in a biosphere atmosphere interac- tion context in the Amazon Region, J. Geophys. Res., 107, 46.146.23, 2002.

Silva Dias, M. A. F., Silva Dias, P. L., Longo, M., Fitzjarrald, D. R., and Denning, A. S.: River breeze circulation in Eastern Amazon: observations and modeling results, Theor. Appl. Climatol., 78, 111-121, 2004.

Silva Dias, P. L., Schubert, W. H., and DeMaria, M.: Large-scale response of the tropical atmosphere to transient forcing, J. Atmos. Sci., 40, 2689-2707, 1983.

Siqueira, J. R. and Machado, L. A. T.: Influence of frontal systems on the day-to-day convection variability over South America, J. Climate, 17, 1754-1766, 2004.

Souza, D. O. and Alvalá, R. C. S.: Observational evidence of the urban heat island of Manaus City, Brazil, Met. Apps., 21, 186193, https://doi.org/10.1002/met.1340, 2014.

Tanaka, L. M., Satyamurty, P., and Machado, L. A.: Diurnal variation of precipitation in central Amazon Basin, Int. J. Climatol. 34, 3574-3584, https://doi.org/10.1002/joc.3929, 2014.

Testud, J., Bouar, E. L., Obligis, E., and Ali-Mehenni, M.: The rainprofiling algorithm applied to polarimetric weather radar data, J. Atmos. Ocean. Tech., 17, 332-356, 2000.

Thalman, R., de Sá, S. S., Palm, B. B., Barbosa, H. M. J., Pöhlker, M. L., Alexander, M. L., Brito, J., Carbone, S., Castillo, P., Day, D. A., Kuang, C., Manzi, A., Ng, N. L., Sedlacek III, A. J., Souza, R., Springston, S., Watson, T., Pöhlker, C., Pöschl, U., Andreae, M. O., Artaxo, P., Jimenez, J. L., Martin, S. T., and Wang, J.: CCN activity and organic hygroscopicity of aerosols downwind of an urban region in central Amazonia: seasonal and diel variations and impact of anthropogenic emissions, Atmos. Chem. Phys., 17, 11779-11801, https://doi.org/10.5194/acp-1711779-2017, 2017.

Tokay, A. and Short, D. A.: Evidence from tropical raindrop spectra of the origin of rain from stratiform versus convective clouds, J. Appl. Meteorol., 35, 355-371, 1996.

Tokay, A., Petersen, W. A., Gatlin, P., and Wingo, M.: Comparison of raindrop size distribution measurements by collocated disdrometers, J. Atmos. Ocean. Tech., 30, 1672-1690, 2013.

Vila, D. A., Machado, L. A. T., Laurent, H., and Velasco, I.: Forecast and Tracking the Evolution of Cloud Clusters (ForTraCC) using satellite infrared imagery: Methodology and validation, Weather Forecast., 23, 233-245, https://doi.org/10.1175/2007WAF2006121.1, 2008.

Wang, D., Giangrande, S. E., Bartholomew, M. J., Hardin, J., Feng, Z., Thalman, R., and Machado, L. A.: The Green Ocean: Precipitation Insights from the GoAmazon2014/5 Experiment, Atmos. Chem. Phys. Discuss., https://doi.org/10.5194/acp-2018-101, in review, 2018.

Wang, J., Krejci, R., Giangrandel, S., Kuang, C., Barbosa, H. M. J., Brito, J., Carbone, S., Chi, X. G., Comstock, J., Ditas, F., Lavric, J., Manninen, H. E., Mei, F., Moran-Zuloaga, D., Pohlker, C., Pohlker, M. L., Saturno, J., Schmid, B., Souza, R. A. F., Springston, S. R., Tomlinson, J. M., Toto, T., Walter, D., Wimmer, D., Smith, J. N., Kulmala, M., Machado, L. A. T., Artaxo, P., Andreae, M. O., Petaja, T., and Martin, S. T.: Amazon boundary layer aerosol concentration sustained by vertical transport during rainfall, Nature, 539, 416-419, 2016.

Weigel, R., Spichtinger, P., Mahnke, C., Klingebiel, M., Afchine, A., Petzold, A., Krämer, M., Costa, A., Molleker, S., Reutter, P., Szakáll, M., Port, M., Grulich, L., Jurkat, T., Minikin, A., and 
Borrmann, S.: Thermodynamic correction of particle concentrations measured by underwing probes on fast-flying aircraft, Atmos. Meas. Tech., 9, 5135-5162, https://doi.org/10.5194/amt-95135-2016, 2016.

Wendisch, M. and Brenguier, J. L. (Eds.): Airborne Measurements for Environmental Research: Methods and Instruments, Wiley-VCH Verlag GmbH \& Co. KGaA, Weinheim, Germany, https://doi.org/10.1002/9783527653218, 2013.

Wendisch, M., Pöschl, U., Andreae, M. O., Machado, L. A., Albrecht, R., Schlager, H., Rosenfeld, D., Martin, S. T., Abdelmonem, A., Afchine, A., Araùjo, A. C., Artaxo, P., Aufmhoff, H., Barbosa, H. M., Borrmann, S., Braga, R., Buchholz, B., Cecchini, M. A., Costa, A., Curtius, J., Dollner, M., Dorf, M., Dreiling, V., Ebert, V., Ehrlich, A., Ewald, F., Fisch, G., Fix, A., Frank, F., Fütterer, D., Heckl, C., Heidelberg, F., Hüneke, T., Jäkel, E., Järvinen, E., Jurkat, T., Kanter, S., Kästner, U., Kenntner, M., Kesselmeier, J., Klimach, T., Knecht, M., Kohl, R., Kölling, T., Krämer, M., Krüger, M., Krisna, T. C., Lavric, J. V., Longo, K., Mahnke, C., Manzi, A. O., Mayer, B., Mertes, S., Minikin, A., Molleker, S., Münch, S., Nillius, B., Pfeilsticker, K., Pöhlker, C., Roiger, A., Rose, D., Rosenow, D., Sauer, D., Schnaiter, M., Schneider, J., Schulz, C., de Souza, R. A., Spanu, A., Stock, P., Vila, D., Voigt, C., Walser, A., Walter, D., Weigel, R., Weinzierl, B., Werner, F., Yamasoe, M. A., Ziereis, H., Zinner, T., and Zöger, M.: ACRIDICON-CHUVA Campaign: Studying Tropical Deep Convective Clouds and Precipitation over Amazonia Using the New German Research Aircraft HALO, B. Am. Meteorol. Soc., 97, 1885-1908, https://doi.org/10.1175/BAMS-D-14$00255.1,2016$.
Williams, E., Rosenfeld, D., Madden, N., Gerlach, J., Gears, N., Atkinson, L., Dunnemann, N., Frostrom, G., Antonio, M., Biazon, B., Camargo, R., Franca, H., Gomes, A., Lima, M., Machado, R., Manhaes, S., Nachtigall, L., Piva, H., Quintiliano, W., Machado, L., Artaxo, P., Roberts, G., Renno, N., Blakeslee, R., Bailey, J., Boccippio, D., Betts, A., Wolff, D., Roy, B., Halverson, J., Rickenbach, T., Fuentes, J., and Avelino, E.: Contrasting convective regimes over the Amazon: Implications for cloud electrification, J. Geophys. Res., 107, 8082, https://doi.org/10.1029/2001JD000380, 2002.

Zhuang, Y., Fu, R., Marengo, J. A., and Wang, H.: Seasonal variation of shallow-to-deep convection transition and its link to the environmental conditions over the Central Amazon, J. Geophys. Res.-Atmos., 122, 2649-2666, https://doi.org/10.1002/2016JD025993, 2017. 